Danmarks geologiske Undersogelse.

III Række. Nr. 7.

\title{
FORHANDLINGERNE
}

i det paa Foranledning af

Det kongelige danske Landhusholdningsselskab

af Danmarks geologiske Undersøgelse nedsatte Udvalg for

\section{Landøkonomiske Jordbundundersøgelser}

ved H. C. Larsen

tilligemed en

Oversigt over de i Finansaaret 1911-12 af Danmarks geologiske Undersøgelse

udførte

\section{Landøkonomiske Arbejder.}

Udgivet af

Kommissionen for Danmarks geologiske Undersøgelse.

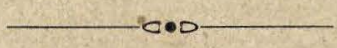

Kjøbenhavn.

I Kommission hos C. A. Reitzel. 1912.

Pris: 50 Øre. 


\title{
Fortegnelse over Danmarks geologiske Undersøgelses Skrifter.
}

\author{
I. Række. \\ Beskrivelser til:Geologisk Kort over Danmark \\ i Maalestok 1:100000.
}

Nr. 1. K. Rørdam. Kortbladene Helsingør og Hillerød. $1893 \ldots \ldots \ldots \ldots \ldots \ldots$. Pris $2,00 \mathrm{Kr}$.

2. N. V. Ussing og Victor Madsen. Kortbladet Hindsholm. $1897 \ldots \ldots \ldots \ldots . \quad 2,00$

3. A. Jessen. Kortbladene Skagen, Hirshals Frederikshavn, Hjøring og Løkken. $1899 \ldots \ldots \ldots \ldots \ldots \ldots \ldots \ldots \ldots \ldots \ldots \ldots . \ldots \ldots$

- 4. A. Jessen. Kortbladene Laesø og Anholt.

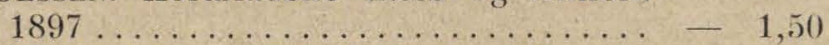

5. Victor Madsen. Kortbladet Samsø. $1897-1,50$

6. K. Rørdam. Kortbladene Kjøbenhavn og Roskilde. $1899 \ldots \ldots \ldots \ldots \ldots \ldots \ldots \ldots$ - 4,00

7. Victor Madsen. Kortbladet Bogense. $1900-2,00$

- 8. K. Rørdam og V. Milthers. Kortbladene Sejrø, Nykjøbing, Kalundborg og Holbæk. $1900 \ldots \ldots \ldots \ldots \ldots \ldots \ldots \ldots$. . . . . . .

9. Victor Madsen. Kortbladet Nyborg. 1902

- 10. A. Jessen. Kortbladene Aalborg og Nibe (nordlige Del). $1905 \ldots \ldots \ldots \ldots \ldots \ldots-4,50$ -

- 11. V. Milthers. Kortbladene Faxe og Stevns Klint. $1908 \ldots \ldots \ldots \ldots \ldots \ldots \ldots \ldots \ldots \ldots \ldots \ldots \ldots+$

- 12. A.Jessen. Kortbladet Skamlingsbanke. $1907-2,00$ -

II. Række.

Afhandlinger om specielle, videnskabelige og praktiske Emner.

Nr. 1. K. Rørdam. Undersøgelse af mesozoiske Lerarter og Kaolin paa Bornholm i geologisk og teknisk Henseende. 1890 . Pris $1,25 \mathrm{Kr}$.

- 2. K. Rørdam. Saltvandsalluviet i det nordostlige Sjælland. $1892 \ldots \ldots \ldots \ldots \ldots-3,00$ -

- 3. K. Rørdam. Geologisk-agronomiske Undersøgelser ved Lyngby Landboskole og Brede Ladegaard. $1894 \ldots \ldots \ldots \ldots \ldots-1,00-$

4. Henr. Posselt. Brachiopoderne i den danske Kridtformation. $1894 \ldots \ldots \ldots-1,25$ - 
Danmarks geologiske Undersøgelse.

III Række. Nr. 7.

\title{
FORHANDLINGERNE
}

i det paa Foranledning af

Det kongelige danske Landhusholdningsselskab

af Danmarks geologiske Undersøgelse nedsatte Udvalg for

\section{Landøkonomiske Jordbundundersøgelser}

\author{
ved H. C. Larsen
}

tilligemed en

Oversigt over de i Finansaaret 1911-12 af Danmarks geologiske Undersøgelse

udførte

\section{Landøkonomiske Arbejder.}

Udgivet af

Kommissionen for Danmarks geologiske Undersøgelse.

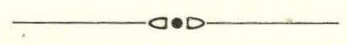

Kjøbenhavn.

I Kommission hos C. A. Reitzel.

1912. 

INDHOLD.

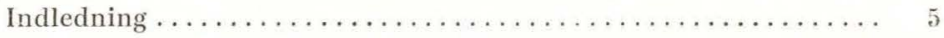

Udvalget for landøkonomiske Jordbundsundersøgelser. En kortfattet Oversigt over dets Forhandlinger. Ved H. C. LARSEN .

Foreløbig Meddelelse om Nedsættelsen af Udvalget for landøkonomiske Jordbundsundersøgelser og om dettes Virksomhed . 24

Danmarks geologiske Undersøgelses landøkonomiske Virksomhed

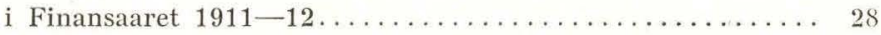

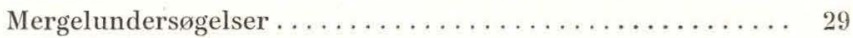

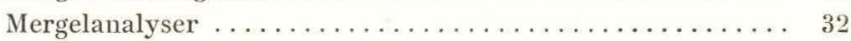

Kalktrangsundersøgelser . . . . . . . . . . . . . 36

Om Mergelundersøgelser, som foretages af Danmarks geologiske Undersøgelse, og om Betingelserne for deres Udførelse ..... 42

Skema til Udfyldning ved Udtagning og Indsendelse af Mergelprøver til Bestemmelse af Kalkindholdet............ 47

Betingelser for Kalktrangsundersøgelser i Jordprøver, som indsendes til Danmarks geologiske Undersøgelse ........... 49

Vejledning ved Vurdering af Resultaterne af Undersøgelserne over

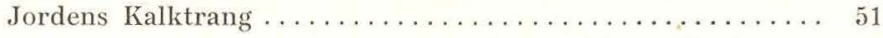

Skema til Udfyldning ved Udtagning og Indsendelse af Jordprøver

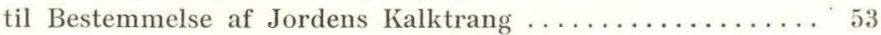

Skema vedrørende lokale Markforsøg til Udfyldning ved Udtagning og Indsendelse af Jordprøver til Bestemmelse af Jordens

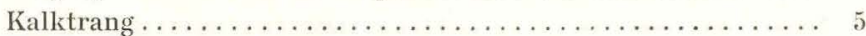




\section{Indledning.}

I de snart 25 Aar, som Danmarks geologiske Undersogelse nu har bestaaet, har $D$. G. $U$.*) stadig haft sin Opmærksomhed henvendt paa de geologiske Forhold, som har - eller kan komme til at faa - praktisk Betydning, og naar Arbejdet paa Hovedopgaven, som er stillet D.G.U., den geologiske Kortlægning af Danmark, har tilladt det, har D. G. U. ikke sjældent foretaget geologiske Undersøgelser med praktiske Formaal for Øje. Dette har medført, at efterhaanden som D. G. U.s Virksomhed er bleven bekendt i videre Kredse, er der i voksende Antal indløbet Forespørgsler om geologiske Forhold af praktisk Betydning. I stedse stigende Grad anvendes D. G. U. som Konsultationsanstalt saavel af offentlige Institutioner som af Private, og dens Bistand søges paa forskellige Maader.

I de senere Aar er der saaledes hyppig bleven rettet Anmodninger til D. G. U. om at yde sagkyndig geologisk Bistand ved eller at paatage sig Udførelsen af Jordbundsundersøgelser af $\mathrm{I}$ a $\mathrm{n} \mathrm{d} ø \mathrm{k}$ o $\mathrm{n}$ o $\mathrm{m}$ i s $\mathrm{k}$ Interesse. Allerede 1906 henvendte det danske Hedeselskab sig til D. G. U. og bad denne assistere sig ved Undersøgelsen af Rindum Mergelleje ved Ringkjøbing; i 1909 ydedes geologisk Bistand ved Hedeselskabets Undersøgelse af Mergellejerne ved

*) Her og i det følgende betegnes Danmarks geologiske Under søgelse ved D. G. $U$. 
Moselund (Engelsvang), Orre pr. Varde, Haraldskjær pr. Skibet og Starup pr. Varde, og D. G. U. overtog for Hedeselskabet Undersøgelsen af Mergellejerne ved Sønder Esp pr. Tim, Lervanggaard pr. Ringkjøbing, Skovlund pr. Sig og Fitting pr. Vorbasse.

1907 modtog D. G. U. en Anmodning fra det af de provinsielle Planteavlsudvalg nedsatte Udvalg til Undersøgelser angaaende Jordernes Kalktrang (»Kalkudvalget«) om at yde sin Bistand ved de Undersøgelser af Jordprøver, som nødvendiggjordes af Kalkudvalgets Arbejder. Da det her drejede sig om en Sag af betydelig Interesse for vort Landbrug, tilsagde D. G. U. Kalkudvalget sin Bistand, og denne ydedes derefter i Aarene 1907-1910.

En lignende Henvendelse modtog D. G. U. 1908 fra afdøde Professor H. Stenbrek paa almindelig dansk Gartnerforenings Forsøgsudvalgs Vegne; ogsaa hertil stillede D. G. U. sig imødekommende.

Paa de provinsielle Planteavlsudvalgs Møde den 5. April 1909 fremhævede Professor T. Westermann Merglingens store Betydning. Han gjorde gældende, at ved den tiltagende intensive Drift indlemmes der i Jorden stigende Mængder af organisk Stof, som producerer Kulsyre, der ved at optages af nedsivende Vand virker opløsende paa Kalken; Jorden kommer derved til at trænge til ny Tilførsel af Kalk. Mergling og Kalkning er derfor ikke Arbejder, der nogensinde kan betragtes som afsluttede; det er Foranstaltninger, som vil have Betydning, saa længe der bestaar Landbrug i Danmark. Under disse Forhold er det vigtigt at faa oplyst, hvorledes vi lettest og billigst kan tilfredsstille denne Kalktrang. Der maa foretages en detailleret Undersøgelse af Landets Mergellejer, saaledes at der, til Brug for den enkelte og for Organisationerne, kan faas Klarhed over, hvor let Adgang der er til Mergel.

Efter at have omtalt D. G. U.s Arbejder og disses store Betydning for Kendskabet til Danmarks Jordbund udviklede Professor Westermann videre, at en systematisk Undersøgelse af Danmarks Mergellejer er en stor og 
omfattende Opgave, som man i Landbrugets Interesse snarest burde tage op. Først og fremmest burde der udføres orienterende Arbejder, for at man kan faa Klarhed over, hvad man kan overkomme, og om Resultaterne af de systematiske Undersøgelser staar i Forhold til Bekostningen og Arbejdet ved dem.

Klitplantør V. Pinholt, Professor, Dr. K. Rørdam, Statskonsulent $K$. Hansen, Forsøgsleder A. J. Hansen, Konsulent M. K. Kristensen o. fl. sluttede sig til Professor Westermann.

Dette gav Anledning til, at de samvirkende danske Landboforeninger allerede den 25. Maj rettede en Henvendelse til $D$. G. U., om denne vilde paatage sig Arbejdet med at planlægge en systematisk Undersøgelse af Mergelen i Landets forskellige Egne. Planteavlsudvalgene vilde i saa Fald anvise passende Arealer til orienterende Undersøgelser, for at man ved Hjælp af saadanne kunde bedømme den heldigste Fremgangsmaade og de med Arbejdet forbundne Udgifter.

D. G. U. erklærede sig under 19. Juni villig til at tage den stillede Opgave op og udbad sig anvist Arealerne til de orienterende Undersøgelser. De samvirkende danske Landboforeninger anviste derpaa den 6. Sept. D. G. U. saadanne Arealer paa Godset Bregentveds Jorder paa Sjæland og mellem Starup og Rigsgrænsen i det sydvestlige Jydland, hvorefter D. G. U. allerede samme Efteraar begyndte denne omfattende Række Undersøgelser, som fortsattes i Somrene 1910 og 1911.

I September 1909 modtog D. G. U. gennem det danske Hedeselskab en Anmodning fra Ringstedegnens Landboforening om at iværksætte en Undersøgelse af Jordbundsforholdene i Ringstedegnen, for at man kunde faa konstateret, hvorvidt og i hvilket Omfang der findes Kalkog Mergellejer, fra hvilke der kan skaffes den nødvendige Mergel, saa at det ikke blev nødvendigt for Landboforeningens Medlemmer at købe Gødningskalk. Da en saadan Undersøgelse vilde faa Betydning for Bedømmelsen af 
den heldigste Fremgangsmaade og Bekostningen ved de paatænkte, systematiske Mergelundersøgelser, lovede D. G. U. Ringstedegnens Landboforening at udføre den ønskede Undersøgelse. Denne fandt Sted i Somrene 1910 og 1911.

Foranlediget ved en Udtalelse af Professor, Dr. phil. $K$. Rørdam ved Generalforsamlingen den 17. December 1909 i Det $\mathrm{kgl}$. danske Landhusholdningsselskab angaaende det ønskelige i at faa forskellige Spørgsmaal vedrørende de landøkonomiske Jordbundsundersøgelser nærmere drøftede i et Udvalg, anmodede Selskabet i Skrivelse af 14. April 1910 Kommissionen for Danmarks geologiske Undersøgelse om at nedsætte et Udvalg med det Formaal:

1) at bringe et Samarbejde i Stand mellem D. G. U., det danske Hedeselskab, de samvirkende danske Landboforeninger og Statens Forsøgsvirksomhed $i$ Plantekultur angaaende de landøkonomiske Jordbundsundersøgelser,

2) at paapege de Opgaver paa de landøkonomiske Jordbundsundersøgelsers Omraade, som det vil være ønskeligt at tage op, og

3) at angive i Hovedtrækkene de Fremgangsmaader, der bør anvendes ved Undersøgelsernes Gennemførelse.

Selskabet henstillede desuden, at Udvalget kom til at bestaa af Repræsentanter for de 4 nævnte Institutioner, som alle har beskæftiget sig med landøkonomiske Jordbundsundersøgelser, samt af Forslagsstilleren, Professor, Dr. phil. K. Rørdam, og, som Repræsentant for Landhusholdningsselskabet, Sekretær H. C. Larsen.

Denne Anmodning var det Kommissionen kært at efterkomme. Den nedsatte det foreslaaede Udvalg, og dette holdt i 1910 en Række Møder, over hvis Forhandlinger der gives en Oversigt i det følgende Afsnit. 


\section{Udvalget for landøkonomiske Jordbunds- undersøgelser.}

En kortfattet Oversigt over dets Forhandlinger.

Ved H. C. Larsen.

Paa Landhusholdningsselskabets Generalforsamling den 17. December 1909 henstillede Professor, Dr. phil. K. Rørdam til Selskabets Præsidium at nedsætte et Udvalg til at tage forskellige Spørgsmaal vedrørende den landøkonomiske Jordbundsundersøgelse under Overvejelse, herunder ogsaa Spørgsmaalet om, paa hvilken Maade de stedfindende landøkonomiske Jordbundsundersøgelser kunde bringes i Samarbejde (jvfr. Tidsskrift for Landøkonomi 1910, Side 286-87).

Jordbundsundersøgelser med specielt landøkonomiske Formaal har ikke hidtil herhjemme - saaledes som Tilfældet er med de almindelige geologiske Undersøgelser været udførte i større Omfang efter en bestemt udformet Plan. I de senere Aar er denne Gren af Jordbundsforskningen imidlertid taget op af forskellige landøkonomiske Institutioner i en noget videre Udstrækning end tidligere, saaledes af Det danske Hedeselskab, De samv. danske Landboforeninger, Statens Forsøgsvirksomhed i Plantekultur og Kommissionen for Danmarks geologiske Undersøgelse. Men nogen nærmere fastslaaet Samvirken mellem Institutionerne var dog endnu ikke etableret, og den $\mathrm{Mu}$ lighed var saaledes ikke udelukket, at der paa den land- 
økonomiske Jordbundsundersøgelses Omraade efterhaanden kunde opstaa sideordnede og delvis konkurrerende Virksomheder, der let vilde kunne medføre Spild af Kræfter og Midler og blive til Skade for en sund og god Udvikling af denne for Landbruget betydningsfulde Sag.

Selskabet ansaa det derfor for meget ønskeligt, at der virkedes hen til et nærmere ordnet Samarbejde mellem Institutionerne om saa vidt muligt bestemt formulerede Opgaver, og det fandt, at et saadant Samarbejde mest passende vilde kunne forberedes gennem et fagkyndigt Udvalg, bestaaende af Repræsentanter for de nævnte Institutioner, samt at Ledelsen af dets Arbejde burde overdrages Kommissionen for Danmarks geologiske Undersøgelse, hvis hidtidige Arbejder sikkert for en væsentlig Del maatte lægges til Grund for de fortsatte Undersøgelser. Selskabet anmodede derfor Kommissionen om paa den anførte Maade at nedsætte et Udvalg med det Formaal:

1) at bringe et Samarbejde i Stand mellem Danmarks geologiske Undersøgelse, Det danske Hedeselskab, De samvirkende danske Landboforeninger og Statens Forsøgsvirksomhed i Plantekultur angaaende de landøkonomiske Jordbundsundersøgelser,

2) at paapege de Opgaver paa de landøkonomiske Jordbundsundersøgelsers Omraade, som det vil være ønskeligt at tage op, og

3) at angive i Hovedtrækkene de Fremgangsmaader, der bør anvendes ved Undersøgelsernes Gennemførelse.

Kommissionen efterkom denne Opfordring, og Udvalget, der blev nedsat i Forsommeren 1910, kom til at bestaa af følgende Herrer: Statsgeolog, Dr. phil. Victor Madsen og Dr. phil. Poul Harder, valgte af Kommissionen for Danmarks geologiske Undersøgelse, Kammerherre, Hofjægermester C. Bech og mag. scient. A. Mentz, valgte af Det danske Hedeselskab, Konsulenterne O. H. Larsen og $M$. K. Kristensen, valgte af de samvirkende danske Landboforeninger, Professor T. Westermann og Laboratoriebestyrer Harald R. Christensen, valgte af Statens For- 
søgsvirksomhed i Plantekultur, samt Professor $K$. Rørdam og Sekretær i Statens Planteavlsudvalg H. C. Larsen som Repræsentant for Landhusholdningsselskabet.

Under Ledelse af Kommissionens Formand, Generalmajor L. le Maire, afholdt Udvalget i Løbet af Sommeren og Efteraaret 1910 en Række Møder, ved hvilke Forhandlingerne formede sig om følgende, af Professor T. Westermann angivne Program for Udvalgets Arbejde:

1. Skaffe Grundlag for Bedømmelse af Jordens Anvendelighed

a. Til forskellig teknisk Brug,

b. Til Grundforbedring af Kulturjord (f. Eks. Mergel),

c. Til Dyrkning.

2. Skaffe Grundlag for Valg af Kulturforholdsregler ved:

a. Grundforbedring af fysiske Egenskaber samt Regulering af Fugtighedsforholdene,

b. Forbedring af kemiske og biologiske Egenskaber (Gødskning, incl. Tilførsel af Kalk),

c. Periodisk Bearbejdning,

d. Valg af Kulturplanter.

3. Skaffe Grundlag for Bedømmelse af Jordens Værdi til Dyrkning:

a. I Handel og Vandel,

b. Som Beskatningsobjekt.

Punkterne 1 a og 3 , om Jordens Bonitering og dens Benyttelse til teknisk Brug, gav Anledning til en Del Diskussion; men en nærmere Udredning af disse i og for sig vigtige Spørgsmaal blev dog af UJdvalget anset for at ligge uden for dets Opgave.

1 b. Grundlag for Bedømmelse af Jordens Anvendelighed til Grundforbedring af Kulturjord.

Mergelundersøgelser. Af Hensyn til Mergelspørgsmaalets store Betydning og til den stigende Interesse for en rationel Opsøgning og Udnyttelse af Mergellejer bør, efter Udvalgets Opfattelse, Mergelundersøgelser foretages i større Omfang end hidtil og efter bestemte Regler.

Følgende R e g l e r f o r U n d e r s ø g e ls e a f M e rg e l fra større Lejer vedtoges: 
1) Mængden af kulsur Kalk i pCt. af Tørstoffet (af den Del af Mergelen, der har en Finhedsgrad af under $2 \mathrm{~mm}$ ) beregnes paa Grundlag af Kulsyrebestemmelser, der foretages ved simple Metoder. Der udføres saa mange Analyser, at man faar et fyldigt Indtryk af Lejets Ensartethed. Om muligt foretages Analyserne paa Gennemsnitsprøver, men disse maa ikke indeholde Mergel af forskellig Beskaffenhed.

2) I et mindre Antal Prøver bestemmes Vandmængden i den jordfugtige Mergel.

3) Vregtfylden af de samme Prøver beregnes paa Grundlag af Rumfangsbestemmelse.

Til de under 2 og 3 næunte Bestemmelser maa ved Undersøgelser i Marken udtages særlige Prøver.

4) Paa Grundlag af Bestemmelserne 1, 2 og 3 angives Indholdet af kulsur Kalk i Mergelen, saaledes som denne forekommer i Lejet, i $\mathrm{kg}$ pr. $\mathrm{m}^{3}$ og pr. $1000 \mathrm{~kg}$ jordfugtig Mergel.

5) Mergelens fysiske (petrografiske) Beskaffenhed angives fyldigt (stenet, stenfri, sandet, leret, brokket, lagdelt, ikke lagdelt) og med Tilføjelse af den geologiske Betegnelse. I særlige Tilfælde bør maaske foretages Lerbestemmelse efter en nærmere fastsat Metode.

6) I et lille Udvalg af Prøver bestemmes Kali og Fosforsyre efter nærmere vedtaget Metode og angives i $\mathrm{kg}$ pr. $\mathrm{m}^{3}$.

7) I særlige Tilfælde foretages Undersøgelser for Kvælstof (absolut Mængde) samt for skadelige Stoffer.

Spørgsmaalet om O r d n ing og Fordeling a A r b e j d e t mellem Institutionerne var Genstand for en meget indgaaende Forhandling, der væsentlig drejede sig om Institutionernes indbyrdes Samarbejde og Medvirkning ved Mergelundersøgelsernes praktiske Gennemførelse. Særlig havde man Opmærksomheden henvendt paa en Deling saaledes, at Mergellejernes Opsøgning overdroges Danmarks geologiske Undersøgelse, medens Ordningen af Arbejdet vedrørende Lejernes Udnytteìse henvistes til Hedeselskabet, og Mergelens Undersøgelse foretoges af en af disse Institutioner. Dette vilde have været stemmende med det Princip, der laa til Grund for Udvalgets Arbejde, at $\mathrm{Opgaverne} \mathrm{bør}$ fordeles mellem Institutionerne, og den enkelte Opgave, d. v. s. en Række ensartede Undersøgelser, f. Eks. Mergelanalyser, $r ø g$ t e s a f 
e $n$ e nkelt Institution. Men det viste sig i dette Tilfælde vanskeligt at gennemføre paa en tilfredsstillende Maade, selv naar der toges særlige Hensyn til de enkelte Undersøgelsers Omfang og Beskaffenhed, da begge de paagældende Institutioner allerede havde paabegyndt delvis de samme Arbejder. Det var derfor en Forudsætning for den trufne Ordning, at de i videst muligt Omfang skulde s a m a rbejde ved de forskellige Arbejders Gennemførelse.

Ved Forhandlingen om Fremgangsmaaden ved Rekvisition af Undersøgelserne lod Udvalget sig særlig lede af Hensynet til Ønskeligheden af, at de lokale Landboforeninger og Husmandsforeninger, i hvilke Mergelspørgsmaalet i længere Tid har staaet paa Dagsordenen, og som bedst vilde kunne virke for Sagen blandt Landmændene i de forskellige Egne af Landet, som Mellemled mellem disse og Institutionerne og som Rekvirenter af Undersøgelserne, blev direkte medvirkende og interesserede i Sagen, samt at Konkurrence med de private kemiske Laboratorier burde undgaas.

Der vedtoges derefter følgende:

"Begæringer om Opsøgning af Mergellejer og Mergelens Undersøgelse rettes til Landboforeningerne eller Husmandsforeningerne, der vil kunne faa Arbejdet gennemført ved Bistand fra Hedeselskabet eller Danmarks geologiske Undersøgelse.

Henvendelser kan dog som hidtil ske direkte til Hedeselskabet.

Til Begæringerne benyttes Skemaer, der udleveres gratis."

T a k s t e r n e saavel for Arbejdet i Marken som for Analyserne skulde fastsættes ved nærmere Forhandling mellem Danmarks geologiske Undersøgelse og Hedeselskabet, idet man vedtog her og ved alle øvrige Undersøgelser, som Udvalget beskæftigede sig med, saa vidt muligt at folge det Princip, at kun de direkte Ud- 
$\mathrm{g}$ i f t e r ved Undersøgelserne dækkes, saaledes at vedkommende Institution hverken faar Gevinst eller Tab derved.

$\mathrm{S} k$ e m a e $\mathrm{r}$ til Begæring om Mergelundersøgelser med Angivelse af Oplysninger om stedlige Forhold og for Mergelprøvernes Vedkommende med Vejledning til Prøveudtagningen blev udarbejdede af Udvalget og faas ved Henvendelse til Landboforeningerne, Husmandsforeningerne eller Hedeselskabet.

Undersøgelse af Mineraljord og $\mathrm{Hu}$ mus jord. Hvor Formaalet er at forbedre en Jords ensidig uheldige Egenskaber, benyttes, som bekendt, foruden Mergel anden Mineraljord, saaledes navnlig Sand eller Ler til Kultivering af Mosejord, sjældnere Humusjord til Agerjord eller Ler til Sandjord. For at kunne sikre sig et godt Resultat af Grundforbedringsarbejdet vil det dog være nødvendigt i hvert enkelt Tilfælde at tage Hensyn til det paagældende Materiales fysiske og kemiske og undertiden ogsaa til dets biologiske Beskaffenhed. Men om de Krav, der i saa Henseende bør stilles under forskellige Forhold, savnes tilstrækkelig fyldig og paalidelig Oplysning.

I Betragtning heraf vedtoges følgende:

"Under Henvisning til de Undersøgelser, der har været planlagte og paabegyndte af Fællesudvalget for Mosedyrkning (se Tidsskrift for Landbrugets Planteavl 1904, 11. Bind, S. 365-75) og Fællesudvalget for Moseundersøgelser (se Aarsberetning om Statens Planteavlsudvalgs Virksomhed 1907-1908, S. 100-104), henleder Jordbundsudvalget de hertil egnede Institutioners (Landbohøjskolen og Statens Forsøgsvirksomhed i Plantekultur) Opmærksomhed paa Betydningen af nærmere Undersøgelser og Forsøg til Vejledning for Grundforbedring af Kulturjorders uheldige ensidige Egenskaber med særligt Henblik paa Undersøgelse af Mineraljord til Grundforbedring af Humusjorder.

Da der dog paa forskellige Omraader, navnlig med Hensyn til de paagældende Jorders kemiske Sammensæt- 
ning (f. Eks. Indhold af Kali og Kalk i Mineraljord til Paaførsel paa Mosejord, Kvælstof i Humusjord til Grundforbedring af Lerjord og Sandjord), haves tilstrækkeligt Grundlag til Bedømmelse af Materialets Anvendelighed bør saadanne Undersøgelser straks kunne iværksættes. Dette kan ligesom for Mergelens Vedkommende ske ved, at Begæringer rettes til Landboforeningerne eller Husmandsforeningerne, der vil kunne faa Arbejdet gennemført ved Bistand fra Hedeselskabet eller Danmarks geologiske Undersøgelse.

Henvendelser kan dog som hidtil ske direkte til Hedeselskabet.

1 c. Grundlag for Bedømmelse af Jordens Anvendelighed til Dyrkning.

Man havde her navnlig Opmærksomheden henvendt paa alle raa Jorder, særlig Hede- og Mosejorder, Klitarealer, udtørret Søbund samt Kær-, Marsk- og Klægjorder. Ofte benyttes Hedejord og andre tarvelige Jorder til Agerkultur, hvor anden Anvendelse maa forudsættes at være mere rentabel. Efter Udvalgets Anskuelse burde der fra interesserede Institutioners Side gøres et Arbejde for gennem Forsøg og Undersøgelser, Indsamling af Oplysninger om Driftsregnskaber o. lign. at tilvejebringe et saa fyldigt Materiale som muligt til Bedømmelse af saadanne Jorders Dyrkningsværdi ved forskellig Benyttelse, saaledes at det kunde blive muligt at angive Grænser for, hvilke Arealer der burde opdyrkes, og hvilke der rettest burde anvendes paa anden Maade.

Udvalget udtalte sig herom saaledes:

"Jordbundsudvalget anser det for ønskeligt, at der søges tilvejebragt større Klarhed over Betydningen af Jordens Art, specielt dens fysiske Egenskaber og Grundvandstandens Højde, for Valget af dens Benyttelse til Plantning, Ager eller Eng m. m.

Som et Forhold af særlig Betydning henstilles til de dertil egnede Institutioner (Hedeselskabet, Hedebruget og 
Landboforeningerne), at der ved Indsamling af Oplysninger og Udvalg af typiske Arealer til nærmere kontrolleret Undersøgelse skaffes Grundlag til Bedømmelse af Rentabiliteten ved Benyttelse af mager Sandjord henholdsvis til Agerbrug og Skovbrug.

2a. Grundforbedring af Jordens fysiske Egenskaber samt Regulering af Fugtighedsforholdene.

Spørgsmaalet om Tilvejebringelse og Undersøgelse af Grundforbedringsmaterialet blev behandlet under Punkt $1 \mathrm{~b}$. Med Hensyn til Grundforbedring af raa Jorder, af hvilke Mose-, Kær-, Dynd- og Marskjorderne spiller den største Rolle, bør, efter Udvalgets Anskuelse, Undersøgelse til Belysning af de Forhold, der har Betydning for saadanne Jorders Kultur, navnlig deres Indhold af Plantenæringsstoffer og deres fysiske Beskaffenhed i forskellig Dybde, Fugtighedsforhold og Betingelser for Afvanding m. v., søges gennemførte i saa stort Omfang som muligt og efter en lignende Plan som den, der følges ved den grundlæggende Undersøgelse af de danske Moser (jvfr. Henvisningerne i Udtalelsen under Punkt 1 b, Side 638, samt »Mosebladet", 1908, Nr. 6).

Ved Jordernes Afvanding bestemmes Drænledningernes Afstand i Forhold til deres Dybde hovedsagelig efter Ingeniør Coldings Formel. Naar Dræningen har virket en Tid, vil Forholdene imidlertid blive forskellige ved de forskellige Jordarter, idet Lerjorderne forandrer Struktur, bliver lettere gennemtrængelige for Vand og afvandes stærkere end tilsigtet. Undersøgelse af forskellige, drænede Jorders Gennemtrængelighed og Kapillaritet vilde derfor være af Betydning for fremtidige Afvandingsarbejder.

Følgende Udtalelser om disse Spørgsmaal vedtoges:

»Ved Grundforbedring af Kulturjord med det Formaal at ændre dens uheldige fysiske Egenskaber anvendes hyppig Tilførsel af Jord med modsatte Egenskaber. (Ler til Mose- og Sandjord, Sand til Mosejord og Kalk til stiv 
Lerjord). I Forbindelse hermed staar Valget mellem Anvendelse af Mergel eller Kalk og mellem forskellige Slags Mergel under givne, lokale Forhold. Ved de hidtil foreliggende Undersøgelser over Virkningen af slige Grundforbedringer har man sædvanlig ikke holdt de fysiske Virkninger ude fra de kemiske og biologiske, hvilket dog i mange Tilfælde vil være af Betydning, og som et Forhold af særlig Vigtighed skal her nævnes Udforskning af den Rolle, som Humusstofferne spiller for Bevarelsen af Fugtigheden i Agerjorden.

Af de raa Jorder er særlig Humusjordernes Grundforbedring af aktuel Betydning, og det maa meget anbefales, at de Planer for Undersøgelsen af Mosejorder, der er vedtagne af » Fællesudvalget for Mosedyrkning « og »Fællesudvalget for Moseundersøgelser", suppleres med Bestemmelser for Undersøgelsen af andre Arter Humusjord (Kærjord, Dyndjord og Marskjord) og gennemføres i saa vid Udstrækning, som muligt.

Ved Regulering af Jordens Fugtighed og særlig ved Afvandingen er der langt fra altid taget fornødent Hensyn til Jordens fysiske Egenskaber (Gennemtrængelighed og Kapillaritet), og det vilde derfor bl. a. være ønskeligt til Vejledning for fremtidige Arbejder af den Art at faa gennemført en Undersøgelse af disse Egenskaber paa drænede Jorder, fra hvilke der maatte foreligge paalidelige Iagttagelser om Resultatet af den foretagne Grundforbedring.

\section{2 b. Forbedring af Jordens kemiske og biologiske} Egenskaber.

Un d e r s øg e ls e r over Jordens Kalk trang blev i 1907-1909 udførte af et Udvalg under de samv. danske Landboforeninger med Bistand af Danmarks geologiske Undersøgelse og Statens Planteavls-Laboratorium. Udførlig Beretning om disse Undersøgelser findes i Tidsskrift for Landbrugets Planteavl, 17. Bind, Side 407-509. Det fremgaar heraf, at man ved Hjælp af simple og billige Metoder i de allerfleste Tilfælde er i Stand til at udtale 
sig med Sikkerhed om Jordens Kalktrang. Selv om Spørgs maalet vel ikke kan siges at være fuldstændig belyst $\mathrm{i}$ all Enkeltheder, er der $\operatorname{dog}$ al mulig Anledning for Landmændene til at benytte sig af de indvundne Resultater ved, forinden Mergling eller Kalkning foretages, at lade Jordprøver fra deres Marker undersøge for derigennem lettere og billigere end ved Forsøg at komme til Kundskab om, hvorvidt der er Sandsynlighed for, at Mergel eller Kalk med Fordel kan anvendes paa vedkommende Arealer, og det maa forudsættes, at Landmænd i stort Antal ønsker Jordprøver undersøgte i saa Henseende.

Spørgsmaalet om s a a d a n n e Und e r s ø g e ls e r s O r d n in g o g G e n n e m f ø r e ls e var derfor Genstand for indgaaende Overvejelse i Jordbundsudvalget, idet man navnlig havde Opmærksomheden henvendt paa at sikre sig en paalidelig sagkyndig Udførelse af Undersøgelserne, for at hele denne vigtige Sag fra første Færd af kunde komme ind i det rette Spor. Metoderne er ganske vist simple, men de kræver dog, særlig ved Azotobacterprøven, en nøje Forstaaelse af biologiske Forhold og tillige landøkonomisk Indsigt, saaledes at der paa Grundlag af Undersøgelserne kan gives Landmændene fornøden Forklaring og Vejledning om Anvendelse af Resultaterne i hvert enkelt foreliggende Tilfælde. Tanken om at henvise Undersøgelserne til de private Laboratorier maatte derfor opgives, da man ikke kunde forudsætte, at disse i Almindelighed sad inde med den fornødne Erfaring og Indsigt paa dette specielle, nye Analyseomraade, og den Vejledning og Kontrol, der af denne Grund vilde være nødvendig ved Udførelsen, ikke kunde etableres.

Det kunde ligeledes vanskelig lade sig gøre at foretage Kalktrangs-Undersøgelserne paa Statens PlanteavlsLaboratorium, hvis Bestyrer har sat disse Undersøgelser i System. Laboratoriet er væsentligst oprettet med Arbejde inden for Statens Forsøgsvirksomhed for Øje og er ikke indrettet paa at udføre Masseundersøgelser. Danmarks geologiske Undersøgelse, der, som anført, havde medvir- 
ket ved de forberedende Arbejder, erklærede sig imidlertid villig til med Bistand af Statens Planteavls-Laboratorium at paatage sig Undersøgelserne, forudsat at de nødvendigste Midler dertil kunde skaffes til Veje, og da en saadan Ordning ogsaa af andre Grunde maatte anses for ønskelig, vedtoges det at søge den gennemført.

Endvidere ansaa man det for ønskeligt paa samme Maade som ved Mergelundersøgelserne at benytte de lokale Landboforeninger og Husmandsforeninger som Mellemled ved Indsamling og Indsendelse af Jordprøverne og Meddelelse af Resultaterne.

Taksterne for Undersøgelserne skulde, under Overholdelse af det samme Princip som ved Mergelanalyserne, fastsættes ved nærmere Forhandling mellem Danmarks geologiske Undersøgelse og Statens Planteavls-Laboratorium.

$\mathrm{S} k$ e m a e r til Begæring om Undersøgelse af Jordprøver og til Meddelelse af Oplysning om Jordbundsforhold m. v. paa de Arealer, hvorfra Prøverne stammer, samt Vejledning til Prøveudtagningen, blev udarbejdede af Udvalget og udleveres ved Henvendelse til Landboforeninger eller Husmandsforeninger. talelse:

Om Sagen i sin Helhed vedtoges i øvrigt følgende Ud-

"Under Henvisning til Resultaterne af de ved de samvirkende danske Landboforeninger med Bistand af Danmarks geologiske Undersøgelse og Statens Forsøgsvirksomhed i Plantekultur udførte Undersøgelser og Forsøg over Fremgangsmaader til Bestemmelse af Jordens Kalktrang udtaler Jordbundsudvalget Ønsket om en Fortsættelse af Undersøgelserne i Forbindelse med Forsøg med kalktrængende Kulturplanter, eventuelt tillige som Karforsøg, for at man kan naa saa stor Klarhed som muligt paa dette vigtige Omraade.

De foreliggende Resultater bør dog allerede nu udnyttes til Vejledning for Landbrugerne, navnlig ved gennem 
simple Undersøgelser af Jordprøver at angive, om der er Sandsynlighed for Kalktrang, eventuelt om der er Anledning til at anstille Dyrkningsforsøg paa den paagældende Jord, for at faa Oplysning om, hvor vidt denne trænger til Kalk, og eventuelt, hvor meget der bør anvendes.

Landmænd, der maatțe ønske saadanne Undersøgelser anstillede, kan ved dertil indrettede Skemaer, som udleveres gratis, rette Henvendelse herom til Landboforeningerne eller Husmandsforeningerne, der vil kunne faa Arbejdet gennemført ved Bistand fra Danmarks geologiske Undersøgelse og Statens Planteavls-Laboratorium.

De anvendte Metoder vil findes angivne i Tidsskrift for Landbrugets Planteavl, 17. Bind, 1910.

Forsøgsledere, Konsulenter o. a., der ønsker yderligere Oplysninger, vil kunne modtage saadanne ved Henvendelse til Statens Planteavls-Laboratorium, Henrik Steffens Vej Nr. 4, København V.\&

Jordbundsundersøgelser i Forbindelse med Markforsøg blev af Laboratoriebestyrer Harald $R$. Christensen foreslaaet gennemførte i langt større Omfang, end Tilfældet hidtil har været. Ligesom ved Undersøgelserne over Jordens Kalktrang vil der herved sikkert kunne opnaas Resultater af stor Betydning for Jordbruget.

Bestemmelse af $\mathrm{J}$ ordens Reaktion og B a s icite $t$ burde foretages ved alle lokale Forsøg. Den er simpel og let at udføre, og den giver et dybt Indblik i Jordbundens hele Tilstand. Den kan foruden om Kalktrang give gode Antydninger om Jordens Trang til forskellige andre, vigtige Plantenæringsstoffer, om ensidige Gødningsstoffers relative Værdi, om plantepatologiske Forhold m. v., og den vil utvivlsomt i mange Tilfælde kunne bidrage væsentlig til Forstaaelse af Forsøgsresultater, hvis Tydning man ellers staar tvivlende overfor. Samtidig med denne Bestemmelse vilde det være af ikke ringe Interesse at foretage en ensartet Bedømmelse af Jordens fy- 
s is k e Tils t a d d (Sværhed, Formuldningsgrad m. v.), hvorved der kunde tilvejebringes et stort Materiale af Betydning for en samlet Bearbejdelse af Forsøgsresultater og for fremtidige Jordbundsundersøgelser.

Som Opgaver for Samarbejde mellem den lokale Forsøgsvirksomhed og Laboratorievirksomhed maa endvidere særlig nævnes Undersøgelser til Bestemmelse af J o r d e n s Fosforsyre- og Kalitrang. Saadanne Undersøgelser vilde formentlig kunne danne en naturlig Fortsættelse af de foretagne Undersøgelser over Jordens Kalktrang. Anlæg af specielle, fleraarige Markforsøg med dette Formaal for Øje vilde være ønskelig, — for Kaliundersøgelsernes Vedkommende er saadanne allerede planlagte; men selv fra almindelige Gødningsforsøg, der giver tydelige Udslag for vedkommende Stof, vil der sikkert kunne skaffes et godt Materiale til Undersøgelserne. Disse maa, for at finde de bedste Metoder, paa Laboratoriet foretages efter forskellige Principper, hvorom der foreligger en Række Planer og Forslag, som agtes benyttede.

Forhandlingerne om Sagen sluttede med følgende Udtalelse:

"I Betragtning af den gennemgribende Indflydelse, som Jordbundens Reaktion og Basicitet udøver paa dens hele Tilstand, og det nære Forhold, der i mange Tilfælde maa antages at bestaa mellem disse Egenskaber og Resultaterne fra en Række forskellige Markforsøg, udtaler Jordbundsudvalget Ønskeligheden af at faa Undersøgelser herover bragte i Forbindelse med Markforsøg og særlig da med Gødningsforsøg, Forsøg med Lucerne, Bælgsædog Frøblandinger og Forsøg til Bekæmpelse af Plantesygdomme.

Endvidere skal Jordbundsudvalget udtale Ønskeligheden af, at der i Fortsættelse af de foretagne Undersøgelser over Fremgangsmaader til Bestemmelse af Jordens Kalktrang paabegyndes lignende Undersøgelser med det Formaal at finde Fremgangsmaader, der kan give Udtryk for Jordens absolutte Trang til andre Plantenæringsstoffer 
og for Øjeblikket da særlig Fosforsyre og Kali, og at der rundt omkring paa forskellige Jordarter kan blive anlagt fleraarige Forsøg med dette særlige Formaal for Øje.»

\section{2 c. Jordens periodiske Bearbejdning.}

Man gaar ved denne frem efter Erfaring og Skøn, og der er mange Meninger om Tidspunkt, Maade, Intensitet og navnlig om den Dybde, hvortil Jorden bør behandles. Dyb Bearbejdning anses for heldig, naar der samtidig kan gødes rigeligt, men der haves mange Eksempler paa, at den har virket skadelig. Spørgsmaalets nærmere Undersøgelse er saaledes af stor Interesse.

Paa lermuldede Jorder ved Askov og Aarslev Forsøgsstationer udføres Forsøg med Dybdebehandling i Forbindelse med forskellig Gødskning; men paa Sand- og Mosejord haves endnu ingen Bearbejdningsforsøg. Enkelte saadanne har været anlagte i Landboforeningerne. men de er nu ophørte, bl. a. fordi det er vanskeligt at finde gode Forsøgssteder. Medens Forsøg med Dybdebehandling maa være stationære, da de skal strække sig over en længere Aarrække, vil mange Bearbejdningsforsøg egne sig godt for ambulant og lokal Forsøgsvirksomhed, og Anlæg af saadanne i Forbindelse med Jordbundsundersøgelser til Belysning af Bearbejdningens Indflydelse paa de forskellige Jorders Tilstand vilde være meget ønskelig.

Følgende Udtalelse herom vedtoges:

Jordbundsudvalget udtaler Ønskeligheden af, at Forsøg vedrørende Jordens periodiske Bearbejdning, specielt m. H. t. Dybden, bringes i Forbindelse med Undersøgelser over Jordens Art og Tilstand, idet man mener, at Arbejdet efter Opgavens Natur maa henvises til Statens eller Landboforeningernes Forsøgsvirksomhed. «

\section{2d. Valg af Kulturplanter.}

Der er herved ikke alene tænkt paa Valget af de enkelte Plantearter og Sorter, men ogsaa paa den Rækkefølge, hvori de bør komme i Sædskiftet, samt paa deres 
relative Ydeevne under forskellige Jordbundsforhold. Til Belysning af disse Forhold vilde Undersøgelse af de forskellige Jordlags Beskaffenhed paa de Steder, hvor Arts-, Varietets- og Sædskifteforsøg udføres, være meget ønskelig.

Udvalget udtalte sig herom saaledes:

"Med Henblik paa den store Indflydelse, Jordens Beskaffenhed i øvre og dybere Lag, Grundvandets Højde m. m. øver paa de forskellige Kulturplanters relative Ydeevne, henstiller Jordbundsudvalget, at der til de af Staten og Landboforeningerne udførte Arts-, Varietets- og Sædskifteforsøg knyttes særlige Jordbundsundersøgelser.《

Sluttelig vedtoges det gennem de Institutioner, der var repræsenterede i Jordbundsudvalget, at støtte et Andragende til Kultusministeriet fra Kommissionen for Danmarks geologiske Undersøgelse om Statsbevilling til Bestridelse af Udgifterne ved de Arbejder, der af Udvalget var henviste til Udførelse under Kommissionen, særlig Mergel- og Kalktrangs-Undersøgelserne. Kommissionen opnaaede herved, første Gang for Finansaaret 1911 - 12, en forøget Bevilling paa 15,000 Kr. til landøkonomiske Jordbundsundersøgelser. 


\section{Foreløbig Meddelelse om Nedsættelsen af Ud- valget for landøkonomiske Jordbundsunder- søgelser og om dettes Virksomhed.}

\section{Henhold til, hvad der blev vedtaget af Udvalget for}

landøkonomiske Jordbundsundersøgelser, offentliggjordes i Begyndelsen af November 1910 følgende:

\section{Landøkonomiske Jordbundsundersøgelser.}

Efter Anmodning af Det kgl. danske Landhusholdningsselskab nedsatte Danmarks geologiske Undersøgelse i afvigte Foraar et Udvalg med det Formaal

1) at bringe et Samarbejde i Stand mellem Danmarks geologiske Undersøgelse, det danske Hedeselskab, de samvirkende danske Landboforeninger og Statens Forsøgsvirksomhed i Plantekultur angaaende landøkonomiske Jordbundsundersøgelser,

2) at paapege de Opgaver, som det vil være ønskeligt at tage op, og

3) at angive i Hovedtrækkene de Fremgangsmaader, der bør anvendes ved Undersøgelsernes Gennemførelse.

Udvalget kom til at bestaa af følgende Repræsentanter for Landhusholdningsselskabet og de 4 nævnte Institutioner:

Sekretær H. C. Larsen, Statsgeolog, Dr. phil. V. Madsen, Dr. phil. P. Harder, Kammerherre C. Bech, mag. scient. A. Mentz, Konsulenterne O. H. Larsen og M. K. Kristensen, Professor T. Westermann og Laboratoriebe- 
styrer Harald R. Christensen samt Professor, Dr. phil. K. Rørdam, der oprindelig ved Henstilling til Landhusholdningsselskabet gav Anledning til Udvalgets Nedsættelse.

Under Ledelse af Formanden for Kommissionen for Danmarks geologiske Undersøgelse, Generalmajor L. le Maire, har Udvalget i Sommerens Løb afholdt en Række Møder, ved hvilke man enedes om Samarbejde paa forskellige Omraader og vedtog at udtale Ønskeligheden af, at der iværksættes landøkonomiske Jordbundsundersøgelser i følgende Retninger:

1. M e r g e I u n d e r s ø g e l s e r. Af Hensyn til Mergelspørgsmaalets store Betydning og den stigende Interesse for en rationel Opsøgning og Udnyttelse af Mergellejer bør Undersøgelser af denne Art foretages i større Omfang end hidtil og efter bestemte, af Udvalget nærmere fastsatte Regler, idet der navnlig tages Hensyn til Lejernes Udstrækning og heldige Beliggenhed samt til Mergelens Indhold af kulsur Kalk, dens fysiske Beskaffenhed og, i særlige Tilfælde, dens Indhold af andre Plantenæringsstoffer, Ler og eventuelt skadelige Forbindelser.

Begæringer om Opsøgning af Mergellejer og Mergelens Undersøgelse rettes til Landboforeningerne eller Husmandsforeningerne, der vil kunne faa Arbejdet gennemført ved Bistand fra Hedeselskabet eller Danmarks geologiske Undersøgelse. Henvendelser kan dog som hidtil ske direkte til Hedeselskabet.

2. Undersøgelser til Bestemmelse af Jordens Kalktrang er hidtil foretagne af et Udvalg under de samvirkende danske Landboforeninger med Bistand af Danmarks geologiske Undersøgelse og Statens Forsøgsvirksomhed i Plantekultur. Disse Undersøgelser, hvorom der er afgivet Beretning i det sidst udkomne Hæfte af Tidsskrift for Landbrugets Planteavl (17. Bd. 3. H.), har givet Resultater, der viser, at man ved Hjælp af simple og billige Undersøgelser i de allerfleste Tilfælde kan udtale sig med Sikkerhed om Jordens Kalktrang. Det maa derfor i høj Grad anbefales Landmændene at lade 
Jordprøver undersøge, for derigennem lettere og billigere end ved Forsøg at komme til Kundskab om, hvorvidt der er Sandsynlighed for, at Mergel eller Kalk med Fordel kan anvendes paa de Arealer, hvorfra Prøverne stammer.

Anmodninger om saadanne Undersøgelser kan rettes til Landboforeningerne eller Husmandsforeningerne, der vil kunne faa Arbejdet gennemført ved Bistand fra Danmarks geologiske Undersøgelse og Statens Planteavls-Laboratorium.

Til Begæringer om de under Punkt 1 og 2 nævnte Undersøgelser benyttes Skemaer, der udleveres gratis ved Henvendelse til Landboforeningerne eller Husmandsforeningerne, samt for Punkt 1's Vedkommende til Hedeselskabet. Vejledning med Hensyn til Prøveudtagningen findes paa Skemaerne.

Betalingen for Undersøgelserne fastsættes ved nærmere Forhandling mellem de paagældende Institutioner, idet der dog saavidt muligt følges det Princip, at kun de direkte Udgifter dækkes.

3. Jordbundsundersøgelser i Forbindelse med Markforsøg bør udføres i større Udstrækning end hidtil. Særlig henledes Opmærksomheden paa Undersøgelser med det Formaal:

at bestemme Jordens Reaktion og Basicitet særlig ved Gødningsforsøg, Forsøg med Lucerne, Bælgsæds- og Frøblandinger, samt Forsøg til Bekæmpelse af Plantesygdomme,

at finde Fremgangsmaader, der kan give Udtryk for Jordens absolute Trang til de forskellige Plantenæringsstoffer, navnlig Fosforsyre og Kali,

at belyse den Indflydelse, som den periodiske Bearbejdning, specielt Dybdebehandlingen, øver paa de forskellige Jorders Tilstand,

at undersøge den Betydning, som Jordens Beskaffenhed i de øvre og dybere Lag, Grundvandets Højde m. m., har for Valget af Kulturplanter og disses relative Ydeevne, 
samt for den Rækkefølge, hvori de bør komme i Sædskiftet.

De to sidstnævnte Grupper af Undersøgelser maa formentlig, alt efter Opgavernes Natur, henvises til Statens eller Landboforeningernes Forsøgsvirksomhed.

4. Undersøgelser a f Mose-, Kær- og D y n d jorder med det Formaal at belyse de Forhold, der har Betydning for deres Kultur, navnlig deres Indhold af Plantenæringsstoffer og deres fysiske Beskaffenhed i forskellig Dybde, Fugtighedsforhold og Betingelser for Afvanding m. m., bør gennemføres i saa vid Udstrækning som muligt og efter en lignende Plan som den, der følges ved den grundlæggende Undersøgelse af de danske Moser.

5. Undersøgelser vedrørende magre S a nd jorders Benyttelse. I Betragtning af, at Hedejorder og andre tarvelige Sandjorder jævnlig benyttes til Agerkultur, hvor anden Anvendelse maa antages at være mere rentabel, henstilles det til Hedeselskabet, Hedebruget og Landboforeningerne at iværksætte Undersøgelser over Betydningen af Jordens Art, specielt dens fysiske Egenskaber og Grundvandstandens Højde, for derigennem at skaffe Grundlag for Bedømmelsen af dens Dyrkningsværdi, henholdsvis til Plantning, Ager og Eng.

Nærmere Redegørelse for Udvalgets Arbejde og Meddelelse om dets Beslutninger vil senere blive offentliggjort af Danmarks geologiske Undersøgelse og Landhusholdningsselskabet. 


\section{Danmarks geologiske Undersøgelses landøko- nomiske Virksomhed i Finansaaret 1911-12.}

I Henhold til, hvad der blev vedtaget af Udvalget for landøkonomiske Jordbundsundersøgelser, ansøgte Kommissionen for Danmarks geologiske Undersøgelse Ministeriet for Kirke- og Undervisningsvosenet om, at dets Bevilling maatte blive forhøjet med $15,000 \mathrm{Kr}$. Et Endringsforslag herom stilledes af Ministeriet til 3. Behandling i Folketinget af Forslaget til Finanslov for Finansaaret 1911 - 12, tiltraadtes af Finansudvalget og vedtoges derefter.

Efter at Bevillingen var givet, organiseredes Danmarks geologiske Undersøgelses landøkonomiske Virksomhed af Statsgeolog, Dr. Victor Madsen med Assistance af Dr. phil. Poul Harder. Overledelsen og Regnskabsvæsenet overdroges af Kommissionen til dens Medlem, Statsgeolog Madsen; til at besørge Kontorarbejdet engageredes Frk. A. Galle. Der oprettedes en Afdeling for Mergelundersøgelser og kemiske Undersøgelser og en Afdeling for Kalktrangsundersøgelser. Ved Mergelafdelingen er Arbejdet i Marken bleven foretaget af Statsgeolog Milthers og Dr. phil. Poul Harder. De kemiske Undersøgelser af Mergelprøverne blev først udførte af cand. polyt. Johs. Witt, Assistent ved den polytekniske Læreanstalts kemi- 
ske Laboratorium; men da denne Ordning frembød adskillige Ulemper og cand. Witt paa Grund af andet Arbejde ikke saa sig i Stand til vedblivende at udføre disse Undersøgelser, indrettedes et Laboratorium i Danmarks geologiske Undersøgelses Lokale, og cand. polyt. A. Erichsen engageredes til at udføre Analyserne i dette.

Ledelsen af Kalktrangsafdelingen overdroges Landbrugskandidat Harald R. Christensen, Bestyrer af Statens Planteavls-Laboratorium, og Frk. cand. pharm. M. Madsen engageredes til at udføre selve Undersøgelserne.

\section{Mergelundersøgelser.}

Statsgeolog V. Milthers har paa Sjæland i Slutningen af $1911 \mathrm{og}$ Begyndelsen af 1912 foretaget Undersøgelser af Mergelforekomster paa 20 Ejendomme i NordøstSjæland efter Anmodning af Frederiksborg Amts Planteavlsforening.

I Jydland foretoges i Slutningen af 1911, efter Anmodning af Formanden for Vind, Vinding $m$. fl. Sognes Landboforening, en Besigtigelse af et Mergelleje paa Husmand Mads Jensens Mark i Askov, N. Omme Sogn, Ringkjøbing Amt.

Mergelen viste sig at være af god Beskaffenhed, men da Stedet ligger i ca. 4 km's Afstand fra Ørnhøj Station, hvorfra Mergelen skulde føres med Ringkjøbing--N. Omme Jernbane, vil det mergelfattige N. Omme Sogn lettere kunne blive forsynet med Mergel fra Ø1strup eller Hover, hvor der findes Mergel af særlig god Kvalitet.

I Marts Maaned 1912 har Statsgeolog Milthers med Ingeniør N. Høy som Assistent i Forbindelse med Hedeselskabet paabegyndt en omfattende Undersøgelse af Mergelforholdene i Egnene Øst og Sydøst for Viborg. Der er foretaget Undersøgelse af et Leje ved Faardal i Viskum Sogn, Øst for Viborg. Der er her i tidligere Tid taget 
megen Mergel, og der har indenfor Taphedens Mergelselskab været stærke Ønsker fremme om at faa Lejet udnyttet af dette Mergelselskab paa Grund af Mergelens fortrinlige Beskaffenhed og Virkeevne. Den foretagne Undersøgelse godtgjorde imidlertid, at Mergelen ligger dækket af altfor tykke og uanvendelige Jordlag til, at en Udnyttelse i stor Stil af Mergellejet er muligt.

Desuden er der foretaget Undersøgelse af to Mergellejer imellem Viborg og Rindsholm. Begge ligger i Kanten af en Bakkeø, som rager op over den senglaciale Flodslette »Falborg Dalen«, der strækker sig i Retningen SØ.-NV. Syd om Viborg. Paa begge Steder har Mergelen vist sig at have en Mægtighed af $10 \mathrm{~m}$ og derover. Disse Undersøgelser, der udføres for Taphedens Mergelselskab, var endnu ikke afsluttede ved Udgangen af Marts Maaned. Ved det ene Leje er en større Udnyttelse dog udelukket paa Grund af Overjordens Mægtighed. For det andet Lejes Vedkommende er Forholdene i den Henseende betydelig gunstigere. Mergelen er paa begge Steder af god Kvalitet.

Undersøgelserne paa de nævnte Steder er fortrinsvis udført ved Dybdeboringer: Skylleboring ned til Mergelen og derefter Tørboring ned igennem Mergelen for at tage Prøver til Undersøgelse af dennes Kalkindhold og øvrige Beskaffenhed.

I Tilknytning til disse Undersøgelser er der desuden foretaget orienterende Undersøgelser i den omliggende Egn med Mergelforekomster for Øje. Det synes at fremgaa af de Undersøgelser, som saaledes i det hele er gjort, at Mergellagene i den paagældende Egn i stor Udstrækning tilhører en Aflejring, der særlig er karakteriseret ved sin Stenfrihed og — paa nogle Steder — ved sin regelmæssige Lagdeling. Aflejringen har tilsyneladende en meget vid Udbredelse og findes saavel under de Flodsletter, der opstod som Afslutning af Indlandsisens Virksomhed her, som i Bakkedragene bag og ved Siden af Flodsletterne. Foruden den praktiske Betydning, en Undersøgelse af 
disse Lag har, har den derfor ogsaa videnskabelig Betydning til Oplysning om dette vigtige Led i de Aflejringer, hvoraf Jordlagene i denne Egn er opbyggede.

Dr. phil. Poul Harder har fortsat og afsluttet sine paa Opfordring af Ringstedegnens Landboforening i 1910 paabegyndte Undersøgelser af Mergelforekomster i Ringsted-Egnen. Ialt er foretaget Undersøgelser paa 63 Ejendomme.

Ringsted-Egnen er en udpræget Moræneler-Egn; saa at sige overalt findes Moræneler med rundt 25 pCt. kulsur Kalk. Hyppig er indblandet Skrivekridt i Morænen, og der kan forekomme rent Skrivekridt, som dog stedse er knust. Indblandingen af Kridtet karakteriserer Ringsted-Egnen og bevirker, at den er en af vore kalkrigeste Egne. »Hvidler", Moræneler med indblandet Kridt, findes over store Strækninger. I særlig Grad gælder det Ringsteds nærmeste Omegn i et Strøg fra c. $4 \mathrm{~km}$ Øst for Ringsted og saa langt Undersøgelsen har strakt sig vestpaa. Fra Adamshøj gaar Hvidleret, bredende sig, mod Vest over Ringsted ad Sorø til. Det indeholder omkring 50 pCt. kulsur Kalk. Forekomster af rent Kridt er naturligvis sjældnere. Betydeligst er den gammelkendte Forekomst ved Allindelille, hvor Kridt findes i store Mængder, ogsaa paa mange Steder, som ikke falder ind under denne Undersøgelse. Forekomsten findes i det bakkede Terrain Nord for Langesø. Længere østpaa findes i samme Bakkeparti en lignende Forekomst ved Mukkergaard. Den er ret betydelig, saa at der vil kunne aabnes en Fællesgrav. Ved Hvalsømagle og ved Sigersted findes derimod i Morænen kun tynde Kridtstriber uden Betydning. En Forekomst ved Fredsgaarde er akkurat saa betydelig, at den kan udnyttes. Hvor der er Kridt, findes som Regel ogsaa Hvidler i ret stor Udstrækning.

I Allindelille har der været en Grav i flere Aar, hvor der kan hentes Kalk mod Betaling. Paa Naboejendommen har Danmarks geologiske Undersogelse vist, at Kridtet kan udnyttes paa lignende Maade. Det samme er Til- 
fældet ved Mukkergaard og Fredsgaarde, hvor man vistnok allerede er begyndt at udnytte Kridtet.

Paa alle de undersøgte Ejendomme findes Mergel. Folk er dog kræsne med dennes Kalkindhold, da der de fleste Steder er let Adgang til at faa meget kalkrig Mergel eller ren Kalk tilkøbs.

Der er udført:

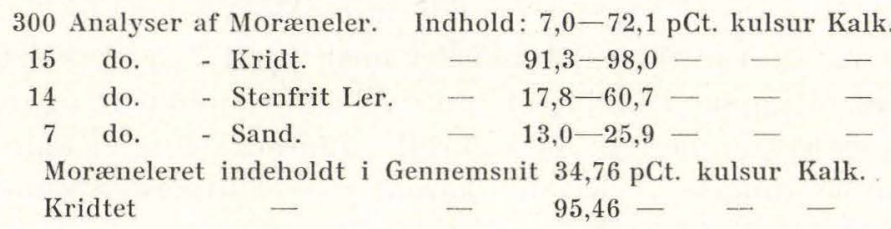

Moræneleret kan inddeles i Grupper:

\begin{tabular}{|c|c|c|c|c|c|}
\hline \multirow{2}{*}{\multicolumn{2}{|c|}{ Moræneler med }} & & Analyser. & Middeltal. & Grænser. \\
\hline & & $0,0-19,9$ pCt. & 42 & 16,42 pCt. & $7,0-19,7 \mathrm{pCt}$ \\
\hline - & - & $20,0-29,9-$ & 101 & $24,44-$ & $20,0-29,8-$ \\
\hline -. & - & $30,0-49,9-$ & 101 & $39,36-$ & $30,4-49,6-$ \\
\hline - & - & $56,0-74,9-$ & 56 & $58,85-$ & $50,2-72,1-$ \\
\hline & & & 300 & & \\
\hline
\end{tabular}

Desuden har Dr. Harder foretaget Undersøgelser af Mergelforekomster paa nogle Ejendomme i Hornsherred efter Anmodning af Frederiksborg Amts Planteavisforening.

\section{Mergelanalyser.}

I Mergelprøver, udtagne ved Danmarks geologiske Undersøgelses Undersøgelser af Mergelforekomster, er udført 498 Bestemmelser af kulsur Kalk, idet Kulsyren er bleven bestemt og Mængden af den kulsure Kalk beregnet, og 18 Bestemmelser af kulsur Kalk, idet Kalken er bleven bestemt og Mængden af den kulsure Kalk beregnet, endvidere 3 Bestemmelser af Jern, 4 af Fosforsyre, 6 af Svovlsyre, 5 af Kvælstof, 35 af Vandindholdet og 34 af Vægtfylden, ialt 603 Bestemmelser. 
I 259 Mergelprøver, der er indsendt af forskellige Landbrugsorganisationer (se nedenfor), er udført $258 \mathrm{Be}$ stemmelser af kulsur Kalk, idet Kulsyren er bleven bestemt og Mængden af den kulsure Kalk beregnet, 17 Bestemmelser af Kali, 13 af Fosforsyre, 1 af Kvælstof, 1 af Vand og 4 af Svovl, ialt 294 Bestemmelser.

Ialt er saaledes udført 897 Bestemmelser.

Kulsyre er bestemt ved Titrering.

Kalk er bestemt ved Fældning af Kalken som Oxalat og Glødning til konstant Vægt.

Kali er bestemt efter Platin-Metoden.

Fosforsyre er bestemt efter Laboratorieforstander $P$. Christensens modificerede Meinckes Metode.

Svovl og

Svovlsyre er bestemt ved Fældning med Klorbaryum. Kvælstof er bestemt efter Kjeldahls Metode.

Vandindholdet er bestemt ved Tørring til konstant • Vagt ved $105^{\circ}$.

Vægtfylden er bestemt ved Hjælp af Steenstrups Vægtfyldebestemmelsesapparat.

Af den følgende Oversigt (S. 34-35) over Antallet af Mergelprøver, der er indsendt af hver enkelt Landbrugsorganisation, og de udførte Analyser, fremgaar det, at 37 Organisationer har benyttet sig af den lette Adgang til at faa undersøgt Mergelprøver, som Danmarks geologiske Undersøgelse har aabnet Landbrugsorganisationerne. De Organisationer, der i størst Udstrækning har ladet Mergelprøver undersøge, er Organisationerne i Frederiksborg Amt (48 Prøver), Aalborg Amt (35 Prøver), Hjøring Amt (62 Prøver) og Vejle Amt (45 Prøver). 


\begin{tabular}{|c|c|c|c|c|c|c|c|}
\hline \multirow[b]{2}{*}{ Amt } & \multirow[b]{2}{*}{ Landboorganisation } & \multirow{2}{*}{ 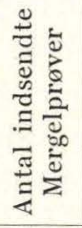 } & \multicolumn{5}{|c|}{$\begin{array}{l}\text { Antal Bestemmelser } \\
\text { af Indhold af }\end{array}$} \\
\hline & & & 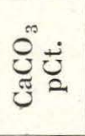 & 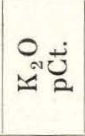 & $0^{\infty} \underbrace{\infty}_{0}$ & 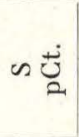 & $\begin{array}{l}0 \\
\text { ond } \\
I \\
I\end{array}$ \\
\hline & $\begin{array}{l}\text { De samv. Landbofor- } \\
\text { eninger i Sj.s Stift. }\end{array}$ & 1 & 1 & & & & \\
\hline 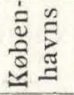 & $\begin{array}{c}\text { Gammel Roskilde Amts } \\
\text { Landboforening .... }\end{array}$ & 2 & 2 & & & & \\
\hline$\stackrel{1}{=}$ & $\begin{array}{c}\text { Frederiksb. Amts Plan- } \\
\text { teavlsforening ...... }\end{array}$ & 46 & 46 & & & & 1 \\
\hline 旅 & $\begin{array}{c}\text { Horns Herreds Land- } \\
\text { boforening .......... }\end{array}$ & 2 & 2 & & & & \\
\hline & $\begin{array}{c}\text { Holbæk Amts Land- } \\
\text { boforening .......... }\end{array}$ & 2 & 2 & & & & \\
\hline$\stackrel{\sharp}{ٍ}$ & $\begin{array}{c}\text { Holbæk Amts økono- } \\
\text { miske Selskab....... }\end{array}$ & 5 & 5 & 4 & 4 & & \\
\hline & $\begin{array}{c}\text { Odsherreds Landbrugs- } \\
\text { forening . . . . . . . . }\end{array}$ & 3 & 3 & & & & \\
\hline & $\begin{array}{l}\text { Ldbf. f. mindre Land- } \\
\text { brugere i Præstø Amt }\end{array}$ & 2 & 2 & & & & \\
\hline 芯 & $\begin{array}{c}\text { Næstved og Omegns } \\
\text { Landboforening ..... }\end{array}$ & 2 & 2 & & & & \\
\hline & $\begin{array}{l}\text { Thureby-Køge og Om- } \\
\text { egns Landboforening }\end{array}$ & 1 & 1 & & & & \\
\hline $\begin{array}{l}0 \\
\vdots \\
0\end{array}$ & $\begin{array}{r}\text { Ringstedegnens Land- } \\
\text { boforening ......... }\end{array}$ & 4 & 4 & & & & \\
\hline $\begin{array}{l}\infty \\
\vdots\end{array}$ & $\begin{array}{l}\text { Aalb. Amts Landbofor. } \\
\text { Nibe- Løgstør og Om- } \\
\text { egns Landboforening }\end{array}$ & 5 & 5 & & & & \\
\hline స్ & $\begin{array}{c}\text { Hadsund og Omegns } \\
\text { Landboforening } . . . .\end{array}$ & 3 & 3 & & & & \\
\hline & Ldbf. Vesthimmerland & 26 & 26 & 1 & 1 & & \\
\hline 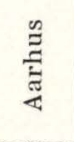 & $\begin{array}{r}\text { Skanderborg Landbo- } \\
\text { forening ............ } \\
\text { Ousted-Taaning Hus- } \\
\text { mandsforening ..... }\end{array}$ & 9 & 9 & & & & \\
\hline$\stackrel{\infty}{\Xi}$ & $\begin{array}{l}\text { Bjergby Husmandsfor. } \\
\text { Tolne Husmandsforen. } \\
\text { Hjørring A.s Landbof. } \\
\text { Flade Husmandsforen. }\end{array}$ & $\left\{\begin{array}{l}6 \\
37 \\
2\end{array}\right.$ & $\begin{array}{r}6 \\
37 \\
2\end{array}$ & 4 & & & \\
\hline
\end{tabular}




\begin{tabular}{|c|c|c|c|c|c|c|c|}
\hline \multirow[b]{2}{*}{ Amt } & \multirow[b]{2}{*}{ Landboorganisation } & \multirow{2}{*}{ 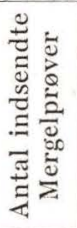 } & \multicolumn{5}{|c|}{$\begin{array}{l}\text { Antal Bestemmelser } \\
\text { af Indhold af }\end{array}$} \\
\hline & & & ن. & ○ी & $\hat{\infty}^{\infty} \underbrace{\infty}$ & n & 乙巳̃ \\
\hline$\stackrel{\infty}{\stackrel{\infty}{\Xi}}$ & $\begin{array}{l}\text { Landboforen. } \quad \text { » Vend- } \\
\text { syssel } \& \ldots \ldots \ldots \ldots \ldots \\
\text { Han Herredernes Land- } \\
\text { boforening . . . . . . . }\end{array}$ & 10 & 10 & 2 & 1 & & \\
\hline 节 & $\begin{array}{l}\text { Kolind Landboforen. . } \\
\text { Grenaa Landboforen. . } \\
\text { Landboforen. for den } \\
\text { nordøstl. Del af Ran- } \\
\text { ders Amt.......... }\end{array}$ & $\begin{array}{l}2 \\
3\end{array}$ & $\begin{array}{l}2 \\
3\end{array}$ & & & & \\
\hline$\stackrel{\check{2}}{\check{2}}$ & $\begin{array}{l}\text { Kolding og Omegns } \\
\text { Landboforening..... } \\
\text { Kolding Vesteregns } \\
\text { Landboforening .... } \\
\text { Vejen-Læborg Husmds- } \\
\text { forening .......... } \\
\text { Ribe Amts vestre Land- } \\
\text { boforeninger ....... }\end{array}$ & 2 & 2 & 1 & 1 & & \\
\hline $\begin{array}{l}\text { Ring- } \\
\text { kjøbg. }\end{array}$ & $\begin{array}{l}\text { Hjerm-Ginding Herre- } \\
\text { ders Landboforening }\end{array}$ & 4 & $\frac{4}{x}$ & & & & \\
\hline$\frac{0}{2}$ & $\begin{array}{l}\text { Kolding Herreds Land- } \\
\text { boforening ......... } \\
\text { Vejleegnens Landbo- } \\
\text { foreninger......... } \\
\text { Brande med Omegns } \\
\text { Landboforening .... }\end{array}$ & 29 & 29 & & 1 & 4 & 1 \\
\hline $\begin{array}{l}\text { Thi- } \\
\text { sted }\end{array}$ & $\begin{array}{l}\text { Landboforeningen } \\
\text { "Nordthy } " \ldots \ldots \ldots\end{array}$ & 1 & 1 & & & & \\
\hline $\begin{array}{l}\infty \\
\vdots \\
\vdots \\
\vdots \\
5\end{array}$ & $\begin{array}{l}\text { Bjerringbro og Om- } \\
\text { egns Husmandsfor- } \\
\text { ening } \ldots \ldots \ldots \ldots \ldots \\
\text { Salling Landbofor- } \\
\text { ening } \ldots \ldots \ldots \ldots \ldots\end{array}$ & 12 & 12 & 3 & 3 & & \\
\hline
\end{tabular}




\section{Kalktrangsundersøgelser.}

I Finansaaret 1911-12 er der foretaget Kalktrangsundersøgelser af 3738 Jordprøver, indsendte gennem 82 Landbo- og Husmandsforeninger.

Der er i alle Tilfælde foretaget kvalitativ Bestemmelse af Jordens Indhold af kulsur Kalk (Brusningsprøven), Bestemmelse af Jordens Reaktion (Lakmusprøven) og biologisk Bestemmelse af Jordens Basicitet (Azotobacterprøven). I de Humusjorder, som ved Azotobacterprøven har vist sig kalktrængende, er der endvidere af Kemikeren foretaget Bestemmelse af Indholdet af klorammoniumopløselig Kalk. Af disse direkte Kalkbestemmelser er der i det forløbne Aar foretaget 43.

Nedenfor er givet en Oversigt over, i hvilket Omfang de enkelte Landbo- eller Husmandsforeninger har benyttet sig af Adgangen til at faa Kalktrangsundersøgelser udførte, og over de fremkomne Resultater. Det fremgaar heraf, at det særlig er Foreninger i Nord-, Midt- og Vestjydland samt i det nordlige Sjæland, der har været interesseret i Arbejdet, et Forhold, der er særdeles naturligt, eftersom det viser sig, at det ganske særlig er indenfor disse Foreningers Omraade, at der forekommer de fleste kalktrængende Jorder. 
Undersøgelser, der foretages i Forbindelse med lokale Markforsøg, udføres gratis, og der er i det forløbne Aar ialt undersøgt Prøver fra 343 lokale Markforsøg, spredte over hele Landet. Naar et tilstrækkelig stort Materiale haves, er det Meningen - i Samarbejde med Landboforeningerne - at foretage en Bearbejdelse af dette for at konstatere Forholdet mellem Jordens Reaktion og Basicitet og dens Produktionsevne og Evne til Udnyttelse af forskellige Gødningsmidler.

Danmarks geologiske Undersøgelse har paa Opfordring demonstreret Fremgangsmaaderne ved Bestemmelse af Jordens Kalktrang samt de opnaaede Resultater ved 3 Udstillinger, nemlig:

Jubilæumsskuet i Hillerød den 23, 24. og 25. Juni.

Ungskuet i Viborg den 13., 14., 15. og 16. Juli.

Industri- og Planteavlsudstillingen i Ringsted den 22., 23. og 24. September.

Desuden er der udlaant Kortmateriale, Skemaer o. 1 . til Brug ved lokale Udstillinger og til Hjælp ved Afholdelse af Foredrag i Landboforeninger.

I den følgende Oversigt (S. 38 -41) er anført Antallet af Jordprøver, der er indsendt af hver enkelt Landbrugsorganisation, de foretagne Undersøgelser og deres Resultater. 


\begin{tabular}{|c|c|c|c|c|c|c|c|c|c|c|c|c|c|}
\hline \multirow[b]{2}{*}{$\vec{\Xi}$} & \multirow{2}{*}{ Landboorganisation } & \multirow{2}{*}{ 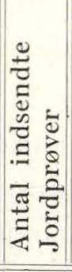 } & \multicolumn{2}{|c|}{$\begin{array}{l}\text { Brus- } \\
\text { ning } \\
\text { med } \\
\text { Syre }\end{array}$} & \multicolumn{3}{|c|}{ Reaktion } & \multicolumn{2}{|c|}{$\begin{array}{c}\text { Azoto- } \\
\text { bacter- } \\
\text { vege- } \\
\text { tation }\end{array}$} & \multicolumn{2}{|c|}{$\begin{array}{l}\text { Kalk- } \\
\text { trang }\end{array}$} & \multirow{2}{*}{ 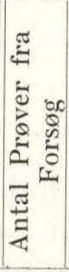 } & \multirow{2}{*}{ 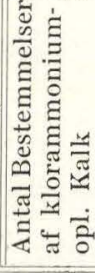 } \\
\hline & & & 范 & $\stackrel{\Xi}{\Xi}$ & $\Xi$ & 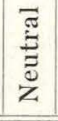 & : & $\begin{array}{l}\tilde{J} \\
\text { o. } \\
\Xi\end{array}$ & 总 & 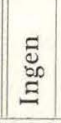 & $\stackrel{5}{2}$ & & \\
\hline & $\begin{array}{c}\text { De samv. Landbofor- } \\
\text { eninger i Sjælands } \\
\text { Stift ............ }\end{array}$ & 33 & 21 & 12 & 3 & 15 & 15 & 10 & 23 & 23 & 10 & 10 & 3 \\
\hline & $\begin{array}{c}\text { De samv. Landbofor- } \\
\text { eningers plantepa- } \\
\text { tologiske Forsøgs- } \\
\text { virksomhed } \ldots \ldots\end{array}$ & 30 & 22 & 8 & 2 & 25 & 3 & 20 & 10 & 10 & 20 & 4 & \\
\hline 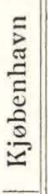 & $\begin{array}{c}\text { Kjøbenhavns Amts } \\
\text { Landboforening... } \\
\text { Gl. Roskilde Amts } \\
\text { Landbof. ......... } \\
\text { Ramsø-Tune Herre- } \\
\text { ders Landbof..... }\end{array}$ & \begin{tabular}{l||}
74 \\
59 \\
23
\end{tabular} & 13 & \begin{tabular}{c|}
36 \\
10
\end{tabular} & 1 & $\begin{array}{l}43 \\
20 \\
14\end{array}$ & 35 & 11 & 19 & 48 & $\begin{array}{r}11 \\
4\end{array}$ & & \\
\hline 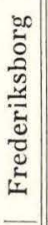 & \begin{tabular}{|} 
Alsønderup Hus- \\
mandsf............ \\
Frederiksborg Amts \\
Planteavilsf........ \\
Horns Herreds Land- \\
bof. ............ \\
Melby Husmandsf. .
\end{tabular} & $\begin{array}{r}256 \\
12 \\
2\end{array}$ & $\begin{array}{r}207 \\
11 \\
2\end{array}$ & 49 & $\begin{array}{l}2 \\
1\end{array}$ & 175 & 50 & 139 & 117 & 117 & 139 & 72 & \\
\hline 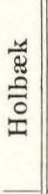 & \begin{tabular}{|} 
Holbæk Amts Land- \\
bof. .............. \\
Holbæk Amts øko- \\
nomiske SeIskab.. \\
Odsherreds Land- \\
brugsf.............
\end{tabular} & $\begin{array}{r}34 \\
104 \\
64\end{array} \mid$ & $\begin{array}{l}42 \\
36\end{array}$ & 62 & 10 & \begin{tabular}{l|}
15 \\
38 \\
22
\end{tabular} & $\begin{array}{l}60 \\
32\end{array}$ & $\begin{array}{c}18 \\
18\end{array}$ & 46 & 46 & $\begin{array}{r}18 \\
18\end{array}$ & & \\
\hline 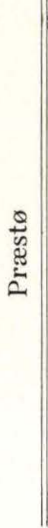 & \begin{tabular}{|} 
Landbof. for mindre \\
Landbrugere i \\
Præstø Amt...... \\
Landbof. for Næst- \\
ved og Omegn.... \\
Landbof. for Stevns, \\
Fakse m. fl. Herr. \\
Præstø Amts Land- \\
bof. ........... \\
Storehedinge Land- \\
sogns Husmandsf.. \\
Stevns Herreds og \\
Omegns Landbof. . \\
Strøby-Varpelev \\
Husmandsf. ..... \\
Tureby-Køge og Om- \\
egns Landbof. ....
\end{tabular} & \begin{tabular}{|r|}
167 \\
47 \\
30 \\
15 \\
3
\end{tabular} & $\begin{array}{l}11 \\
12\end{array}$ & 24 & 1 & $\begin{array}{r}11 \\
12\end{array}$ & $\begin{array}{c}27 \\
18\end{array}$ & 22 & 145 & $\mid \begin{array}{c}40 \\
26\end{array}$ & 22 & 2 & \\
\hline
\end{tabular}




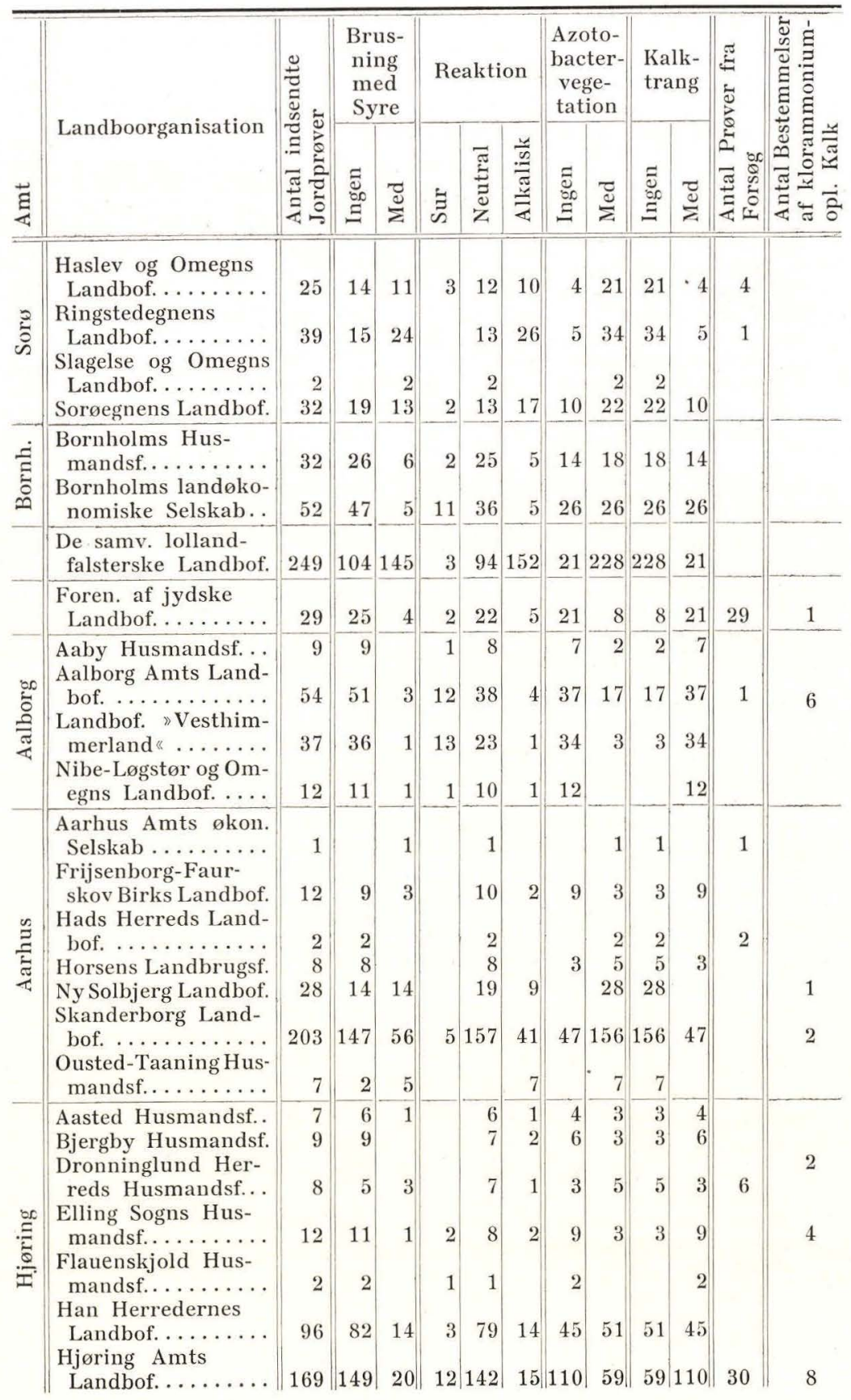




\begin{tabular}{|c|c|c|c|c|c|c|c|c|c|c|c|c|c|}
\hline \multirow[b]{2}{*}{$\vec{\Xi}$} & \multirow{2}{*}{ Landboorganisation } & \multirow{2}{*}{ 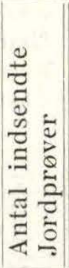 } & \multicolumn{2}{|c|}{$\begin{array}{l}\text { Brus- } \\
\text { ning } \\
\text { med } \\
\text { Syre }\end{array}$} & \multicolumn{3}{|c|}{ Reaktion } & \multicolumn{2}{|c|}{$\begin{array}{l}\text { Azoto- } \\
\text { bacter- } \\
\text { vege- } \\
\text { tation }\end{array}$} & \multicolumn{2}{|c|}{$\begin{array}{l}\text { Kalk- } \\
\text { trang }\end{array}$} & \multirow{2}{*}{ 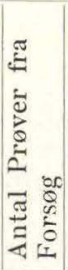 } & \multirow{2}{*}{ 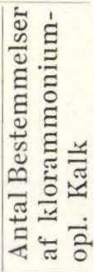 } \\
\hline & & & $\begin{array}{l}\text { ฮే } \\
\text { on } \\
\Xi\end{array}$ & $\stackrel{\Xi}{0}$ & 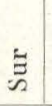 & 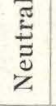 & 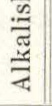 & $\begin{array}{l}a \\
d \\
= \\
=\end{array}$ & $\sum^{0}$ & 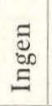 & $\sum_{0}^{2}$ & & \\
\hline 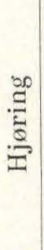 & $\begin{array}{l}\text { Hjøring Amts Hus- } \\
\text { mandsf.. . . . . . . } \\
\text { Landbof. »Vendsys- } \\
\text { sel ............ } \\
\text { KellerupHusmandsf. } \\
\text { Tolne Husmandsf. . } \\
\text { Torslev Husmandsf. } \\
\text { VolstrupHusmandsf. }\end{array}$ & $\begin{array}{r}19 \\
108 \\
8 \\
1 \\
1 \\
2\end{array}$ & $\begin{array}{r}93 \\
5 \\
1 \\
1 \\
2\end{array}$ & $\begin{array}{r}15 \\
3\end{array}$ & $\begin{array}{l}8 \\
2\end{array}$ & $\begin{array}{r}87 \\
5 \\
1 \\
1 \\
2\end{array}$ & $\begin{array}{r}13 \\
1\end{array}$ & $\begin{array}{r}75 \\
1 \\
1 \\
1 \\
2\end{array}$ & $\begin{array}{r}33 \\
7\end{array}$ & $\begin{array}{r}33 \\
7\end{array}$ & $\begin{array}{r}75 \\
1 \\
1 \\
1 \\
2\end{array}$ & 13 & , \\
\hline 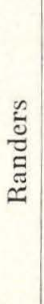 & $\begin{array}{l}\text { Grenaa Landbrugsf. } \\
\text { Landbof. for den } \\
\text { nordøstlige Del af } \\
\text { Randers Amt..... } \\
\text { Landbof. ved Kalø } \\
\text { Vig.............. } \\
\text { Randers og Omegns } \\
\text { Husmandsf. . . . . . } \\
\text { Rougsø-Sønderhald } \\
\text { Herreders Landbof. }\end{array}$ & $\begin{array}{r}27 \\
111 \\
7\end{array}$ & $\begin{array}{l}23 \\
95\end{array}$ & $\begin{array}{r}4 \\
16 \\
3\end{array}$ & 4 & $\begin{array}{l}20 \\
88\end{array}$ & 19 & $\begin{array}{r}21 \\
17 \\
2\end{array}$ & 94 & $\begin{array}{r}6 \\
94 \\
5\end{array}$ & $\begin{array}{l}21 \\
17\end{array}$ & & \\
\hline$\stackrel{\ddot{\Xi}}{\ddot{2}}$ & $\begin{array}{l}\text { Folding Sogns Hus- } \\
\text { mandsf........... } \\
\text { Kolding Omegns } \\
\text { Landbof. . . . . . . } \\
\text { Kolding Vesteregns } \\
\text { Landbof. . . . . . . } \\
\text { Ribe Amts vestre } \\
\text { Landboforeninger . } \\
\text { Vejen-Læborg Hus- } \\
\text { mandsf........... }\end{array}$ & $\begin{array}{r}207 \\
19 \\
267 \\
38\end{array}$ & $\begin{array}{r}194 \\
16 \\
250 \\
38\end{array}$ & 17 & $\begin{array}{r}7 \\
76\end{array}$ & $\begin{array}{r}186 \\
10 \\
172 \\
36\end{array}$ & 19 & $\begin{array}{r}160 \\
17 \\
216 \\
37\end{array}$ & \begin{tabular}{r|}
2 \\
51 \\
1
\end{tabular} & $\begin{array}{r}2 \\
51 \\
1\end{array}$ & $\begin{array}{r}160 \\
17 \\
216 \\
37\end{array}$ & $\begin{array}{r}1 \\
24 \\
7 \\
23 \\
4\end{array}$ & 3 \\
\hline 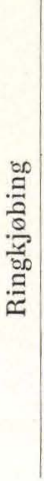 & $\begin{array}{l}\text { Hjerm-Ginding Her- } \\
\text { reders Husmandsf. } \\
\text { Hjerm-Ginding Her- } \\
\text { reders Landbof. . . } \\
\text { Naur Husmandsf. . } \\
\text { Skodborg-Vandfuld } \\
\text { Herreders Landbof. } \\
\text { S. Felding-Assing- } \\
\text { Skarrild og Omegns } \\
\text { Landbof. . . . . . . } \\
\text { Ulfborg-Hind Herre- } \\
\text { ders Landbof. . . . } \\
\text { Ulf borg og Omegns } \\
\text { Landbof. . . . . . . } \\
\text { Vorgod-Brejning m. } \\
\text { fl. Sognes Landbof. }\end{array}$ & $\begin{array}{l}14 \\
12 \\
28 \\
16\end{array}$ & $\begin{array}{l}18 \\
15\end{array}$ & $\begin{array}{r}4 \\
10\end{array}$ & 2 & $\begin{array}{l}20 \\
11\end{array}$ & 21 & $\begin{array}{r}41 \\
3 \\
15\end{array}$ & 16 & 16 & $\begin{array}{r}41 \\
3\end{array}$ & 18 & 1 \\
\hline
\end{tabular}




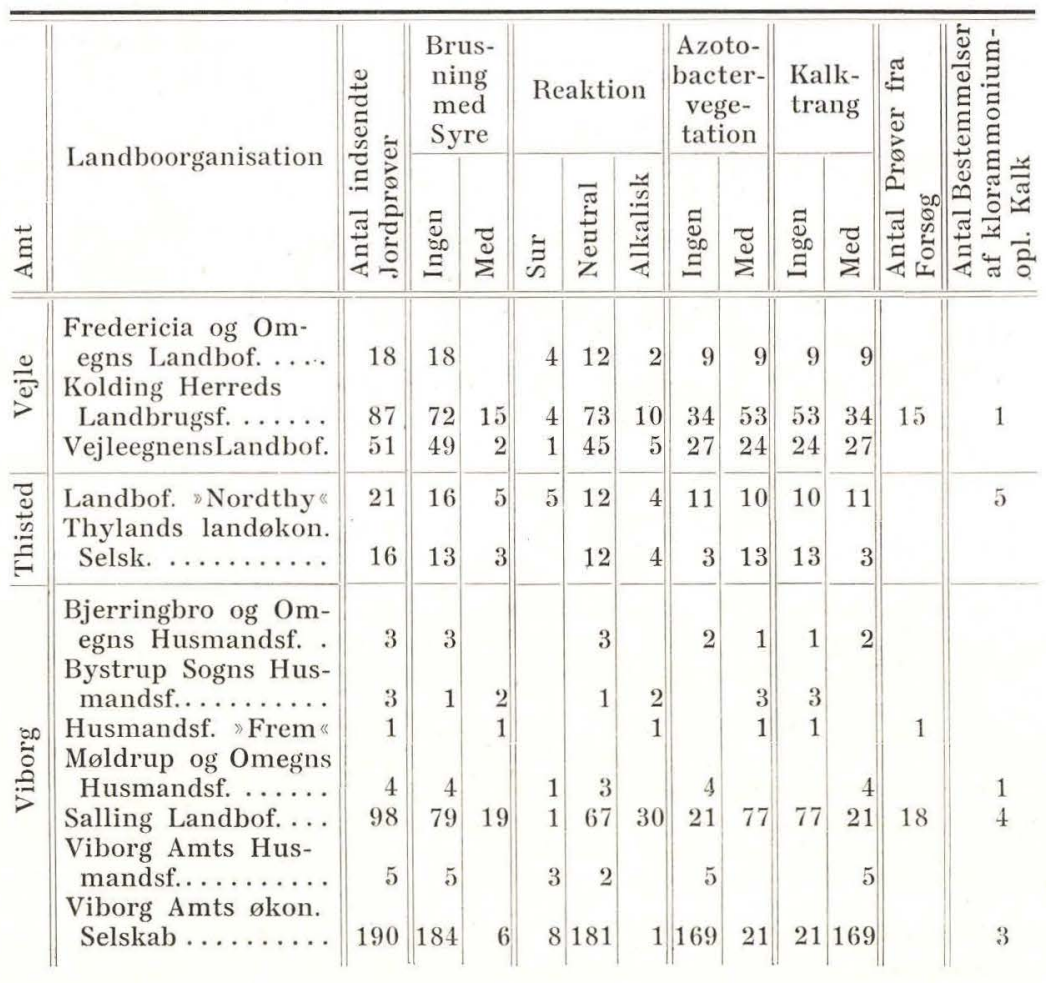




\section{Om Mergelundersøgelser,}

som foretages af

Danmarks geologiske Undersøgelse, og om Betingelserne for deres Udforelse.

I Henhold til Aftale mellem Repræsentanter for Landbrugets Organisationer og Danmarks geologiske Undersøgelse tilbyder sidstnævnte Institution Landbo- og Husmandsforeninger at udføre dels stedlige Undersøgelser af Mergelforekomster og dels Analyser af indsendte Mergelprøver.

\section{Stedlige Undersøgelser af Mergelforekomster.}

\section{a. Almindelige Bemærkninger.}

Ved stedlige Undersøgelser af Mergelforekomster tilstræbes det ved Boringer at bestemme, om Mergelen er til Stede i den nødvendige Mængde, samt at skaffe Oplysninger om Lejringsforholdene (Overjordens Mægtighed, mulig Tilstedeværelse af vandførende Lag og lignende praktiske Forhold, som har Betydning ved Gravningen af Mergelen). Ved Undersøgelse af Boreprøverne i Laboratoriet bedømmes Mergelens Kvalitet.

Undersøgelsen i Marken (Boringerne) maa efter Opgavens Natur ske paa forskellig Maade. Agter man at aabne en større Mergelgrav til fælles Brug for en Del Lodsejere, eller maaske til Mergelforsyning af en hel Egn, kan der blive Tale om at tage Mergelen op fra temmelig stor Dybde, og der maa i saa Tilfælde anvendes Dybdeboringer ved Forundersøgelsen. Drejer det sig derimod kun om Anlæg af Mergelgrave til Enkeltmands Brug, kan man naa tilstrækkelig Dybde med Haandboringer. Den førstnævnte Art af Undersøgelser vil fortrinsvis forefalde i mergelfattige Egne, hvor Landbrugerne slutter sig 
sammen i "Mergelselskaber", medens den anden Type navnlig vil komme til Anvendelse i Landets bedre Egne, hvor der ofte findes Mergel paa hver Mands Mark. Som det vil fremgaa af det følgende, maa ikke blot hele Fremgangsmaaden men ogsaa den nødvendige Tid og Bekostning blive forskellig i de to Tilfælde.

\section{b. Undersøgelse ved Dybdeboringer.}

Ved Undersøgelser paa Steder, hvor det paatænkes at aabne store Mergelgrave til fælles Brug, benyttes som nævnt Dybdeboringer. I saadanne Tilfælde foretages der dog i Reglen altid først en Besigtigelse eller foreløbig Undersøgelse af Mergellejet. Herved tilstræbes det ved Hjælp af smaa Haandbor at fastslaa Mergelens Udstrækning $\mathrm{i}$ vandret Retning, og samtidig bestemmes Overjordens Mægtighed paa en Række Punkter. Om muligt udtages enkelte Mergelprøver til foreløbige Analyser. Endvidere søger man ved Besigtigelsen at danne sig et Skøn over Varighed af og de nærmere Omstændigheder ved den endelige Undersøgelse ved Dybdeboringer.

Har den foreløbige Undersøgelse vist, at Mergelen har den nødvendige Udstrækning i vandret Retning, og at Mergelens Kalkindhold er tilfredsstillende, foretages senere den endelige Undersøgelse ved Hjælp af Dybdeboringer. Samtidig hermed udføres en Opmaaling af Lejet, saa at der kan fremstilles et Nivellementskort, hvorpaa alle Boringer er indlagte.

Ved Undersøgelsen i Marken maa Rekvirenten af Undersøgelsen afgive den fornødne Medhjælp (2 à 3 Mand efter Omstændighederne), fri Vognbefordring og eventuelt frit Ophold til Boremesteren.

Efter at Undersøgelsen i Marken er afsluttet, og der er foretaget Analyser af de derved indsamlede Mergelprøver, udarbejdes en Redegørelse for Resultaterne af hele Undersøgelsen. Denne fremsendes - sammen med en Tegning, visende Boreprofilerne og det nævnte Kort over Lejet - til den paagældende Forening.

\section{c. Undersøgelse ved Haandboring.}

Ved Undersøgelser paa Steder, hvor det paatænkes at aabne mindre Mergelgrave til Enkeltmands Brug, foretages som Regel kun en enkelt Boring paa hvert Sted. Denne udføres med Haandbor og kan derfor under almindelige Forhold ikke føres dybere end 4 à 5 Meter.

Ligesom ved Dybdeboringer maa Rekvirenten afgive den fornødne Medhjælp (1 à 2 Mand efter Omstændighederne). 
Efter at Undersøgelsen i Marken er udført, og der er foretaget Analyser af de udtagne Boreprøver, udarbejdes en Redegørelse for Undersøgelsens Resultater. Denne fremsendes til den paagældende Forening, som sender den videre til de enkelte Landbrugere.

Af Hensyn til Bekostningen (se nedenfor) vil Undersøgelser som de her omtalte fortrinsvis finde Anvendelse, naar en Del Lodsejere i samme Egn ønsker dem udførte. Det maa derfor navnlig ved saadanne Undersøgelser blive de lokale Foreningers Opgave at foranledige og organisere Arbejder af denne Art. Ønsker kun en enkelt Landbruger en stedlig Undersøgelse af en mindre Mergelforekomst, vil Bekostningerne blive forholdsvis store, og der kan derfor i saadanne Tilfælde være Anledning til at overveje, om ikke Analyser af indsendte Mergelprøver vil kunne være tilstrækkelig oplysende for Landbrugeren,

\section{d. Anmodning om Undersøgelse.}

Anmodning om Udførelse af stedlige Undersøgelser af Mergelforekomster sker skriftlig til Danmarks geologiske Undersøgelse, Gammelmønt 14, Kjøbenhavn K. Der maa gives nærmere Oplysninger om Undersøgelsens Art og andre Forhold, som kan have Interesse ved Udførelsen. Oplyses der om det belejligste Tidspunkt for Undersøgelsens Udførelse, vil der saa vidt muligt blive taget Hensyn hertil. Det bemærkes dog, at Undersøgelser i Marken som Regel kun foretages i Sommerhalvaaret. Hvis Anmodningen er Danmarks geologiske Undersøgelse i Hænde inden 1. Marts, udføres Undersøgelsen samme Sommer; skulde dette undtagelsesvis ikke være muligt, skal der straks blive fremsendt Meddelelse herom.

\section{e. Betaling.}

Til Grund for Beregningen af Betalingen for stedlige Mergelundersøgelser, som udføres af Danmarks geologiske Undersøgelse for Landbo- eller Husmandsforeninger, lægges det Princip, at kun de direkte Udgifter, som foranlediges ved Undersøgelsen, søges dækkede. I de nærmere Enkeltheder benyttes følgende Regler:

Rekvirenten af Undersøgelsen godtgør Udlægene til Transport af Redskaber og til Personalets Rejseomkostninger og Dagpenge. Disse sidste er 4 à $6 \mathrm{Kr}$. for Undersøgeren og 4 à $5 \mathrm{Kr}$. for Boremesteren (naar der anvendes Dybdeboring). Dis s e B estemmelser kan dog læmpes, naar Undersøgelsen har In- 
teresse for en videre Befolkningskreds (f. Eks. større Mergellejer i mergelfattige Egne). En Besigtigelse eller foreløbig Undersøgelse af et Mergelleje vil saaledes i Reglen ske gratis, naar den maa foretages lejlighedsvis (ellers maa Udgifterne godtgøres). Naar den endelige Undersøgelse efterfølges af en Udnyttelse af Lejet, dækkes de afholdte Udgifter af Rekvirenten; i modsat Fald er den som Regel gratis. Er Rekvirenten Ejer af Lejet, dækkes dog altid de afholdte Udgifter.

Analyser af Prøver, udtagne ved stedlige Undersøgelser af Mergelforekomster, betales efter nedenstaaende Takster. Kun i de Tilfælde, hvor de nævnte Undersøgelser udføres gratis, beregnes intet for Analyserne. Betalingen er for Bestemmelse af:

1. Kulsur Kalk (Kulsyrebestemmelse) . . . . . . Kr. 0,50

2. Vægtfylde (og Vand). . . . . . . . . . . . . - 1,00

3. Kalk, Kali, Fosforsyre, Svovl og Kvælstof for hver - 2,00

Betalingen for udførte Undersøgelser føres Rekvirenten i Regning. Opgørelse finder Sted pr. 1. Januar.

Danmarks geologiske Undersøgelse har, ligesom de Landbrugsorganisationer, der har foranlediget Undersøgelserne, Ret til eventuelt at benytte Resultaterne af disse til Offentliggørelse.

\section{Analysering af indsendte Mergelprøver.}

Ved Indsendelse af Mergelprøver til Analyse for kulsur Kalk benyttes en ganske lignende Forretningsgang som ved Indsendelse af Jordprøver til Bestemmelse af Jordens Kalktrang; den fremgaar af følgende:

Skemaer til Benyttelse ved Indsendelse af Prøver leveres Foreningerne gratis og portofrit ved Henvendelse til Danmarks geologiske Undersøgelse. Før Benyttelsen forsynes de i Hjørnet foroven til venstre med Foreningens eller Konsulentens Stempel eller Underskrift, for at man tydeligt kan se, hvortil Regning kan sendes. Prøver, der maatte indkomme uden Skemaer, tages ikke i Arbejde, før de tilsvarende Skemaer er indgaaede.

Nummererede Blikdaaser, egnede til Prøvernes Forsendelse, leveres paa samme Maade gratis og portofrit fra Danmarks geologiske Undersøgelse, men dog saaledes, at hver Sending Daaser debiteres Foreningen med 5 Øre pr. Daase, og at de Daaser, som indkommer med Prøver, atter godskrives Foreningen med samme Beløb. 
Prøverne udtages efter den paa Bagsiden af Skemacrne anførte Vejledning. For hver Prøve udfyldes et Skema saa fuldstændigt som muligt.

Prøverne indsendes til Danmarks geologiske Undersøgelse, Gammelmønt 14, København K., enten af den stedlige Landbo- eller Husmandsforening (Konsulenten) eller af den enkelte Landmand. I det sidste Tilfælde maa det tydeligt fremgaa af Skemaet, til hvem Resultater og Regning kan sendes.

Undersøgelsens Resultater, der som Regel ikke kan ventes, før ca. 14 Dage efter Prøvernes Modtagelse, sendes til Konsulenten eller en anden Mand, udpeget af den Forening, der har stemplet og udleveret Skemaet.

Betalingen for Bestemmelse af kulsur Kalk i indsendte Mergelprøver er fastsat til 50 Øre pr. Prøve*). Beløbene føres Foreningen i Regning, og Opgørelse finder som Regel Sted kvartalsvis. Opgørelsen stiles til Foreningen og sendes til den, der har modtaget Resultaterne af Undersøgelsen.

De indsendte Skemaer skal bero hos Danmarks geologiske Undersøgelse, der ligesom de Landbrugsorganisationer, som har indsendt Jordprøverne, har Ret til eventuelt at benytte Resultaterne af Undersøgelserne til Offentliggørelse.

*) Ønskes undtagelsesvis andet end kulsur Kalk bestemt i indsendte Mergelprøver, maa dette fremgaa af Skemaerne. For saadanne Analyser er fastsat følgende Takster: For Bestemmelse af Kalk, Kali, Fosforsyre, Svovl og Kvælstof $2 \mathrm{Kr}$. for hver Bestemmelse og for Vægtfylde (og Vand) 1 Kr. Denne sidste Bestemmelse udføres kun med bele, sammenhængende Prøver. 
Foreningens eller Konsulentens Stempel eller Underskrift.

\section{Skema}

til Udfyldning ved Udtagning og Indsendelse af Mergelprøver til Bestemmele af Kalkindholdet.

Til

Landboforening.

Husmandsforening,

Mergelprøve Nr.

i Daase $\mathrm{Nr}$

udtagen af (Stilling, Navn

og Adresse) den / $191 \ldots$

hos (Stilling, Navn, Bynavn, Postadr.)

Medlem af

Landboforening.

Husmandsforening.

Indsendt d. / 191

\begin{tabular}{|c|c|}
\hline Sporgsmaal: & Svar: \\
\hline \multicolumn{2}{|l|}{$\begin{array}{l}\text { 1. Mergellejets Beliggenhed: } \\
\text { a) Matrikelnummer? } \\
\text { b) Afstand fra Boligen? } \\
\text { c) Retning i Forhold til } \\
\text { samme? }\end{array}$} \\
\hline $\begin{array}{l}\text { 2. Hvor dybt ligger Mergelen } \\
\text { under Overfladen? }\end{array}$ & Fod \\
\hline 3. Mergellagets Tykkelse? & Fod \\
\hline $\begin{array}{l}\text { 4. Mergellagets Udstræk- } \\
\text { ning? }\end{array}$ & Skpr. Ld. \\
\hline $\begin{array}{l}\text { 5. Tiden for Lejets Benyt- } \\
\text { telse? }\end{array}$ & $\begin{array}{l}\text { fra Aar til Aar } \\
\text { særligt i Aar }\end{array}$ \\
\hline \multicolumn{2}{|l|}{ 6. Benyttes Lejet for Tiden? } \\
\hline \multicolumn{2}{|l|}{$\begin{array}{l}\text { 7. Sælges der Mergel fra } \\
\text { Lejet? }\end{array}$} \\
\hline \multicolumn{2}{|l|}{$\begin{array}{l}\text { 8. Hvor stort et Areal er } \\
\text { merglet fra Lejet? }\end{array}$} \\
\hline $\begin{array}{l}\text { 9. Hvor megen Mergel an- } \\
\text { vendes sædvanlig pr. Td. } \\
\text { Ld.? }\end{array}$ & \\
\hline \multicolumn{2}{|l|}{$\begin{array}{l}\text { 10. Omkostninger ved Op- } \\
\text { gravning af Mergelen? }\end{array}$} \\
\hline $\begin{array}{l}\text { 11. Hvad kaldes Mergelen } \\
\text { (Lermergel, Sandmergel, } \\
\text { Kalkmergel o. s. v.)? }\end{array}$ & \\
\hline
\end{tabular}

Vend! 


\begin{tabular}{l||l}
\hline \multicolumn{1}{|c|}{ Spørgsmaal: } & Svar: \\
\hline 12. Er Prøven taget af op- \\
gravet Mergel eller i \\
Grav?
\end{tabular}

\section{Vejledning ved Prøveudtagningen.}

1. Prøven bør udtages saaledes, at den er absolut fri for Indblanding af Jord eller Mergel fra andre Lag end det, man ønsker Prøven udtaget af.

2. Til Prøveudtagning vælges et Sted, hvor Mergelen har et typisk Udseende, og der udtages $1 / 2-1$ Pd. Er Mergelen forskelligartet, bør der udtages flere Prøver.

3. Indenfor Indpakningen lægges, indsvøbt i Avispapir, en Følgeseddel, hvorpaa angives Afsenderens Navn og Adresse, samt et Nummer, hvis der indsendes flere Prøver.

4. Sammen med Prøven indsendes omstaaende Skema, udfyldt saa fuldstændigt som muligt. Indsendes flere Prøver, udfyldes et Skema for hver, mærket med Prøvens Nummer - og hvis der benyttes nummererede Daaser, da tillige Daasens Nummer.

5. Prøverne sendes til Danmarks geologiske Undersøgelse, Gammelmønt 14, Kjøbenhavn K. Forsendelsen sker bedst som Postpakke. 


\section{Betingelser}

for Kalktrangs-Undersogelser i Jordprover, som indsendes til Danmarks geologiske Undersøgelse.

I Henhold til Aftale mellem Repræsentanter for Landbrugets Organisationer og Danmarks geologiske Undersøgelse tilbyder sidstnævnte Institution Landbo- og Husmandsforeninger Undersøgelse af Jordprøver til Bedømmelse af Jordens Kalktrang. Ved dette Arbejde anvendes følgende Forretningsgang:

Skemaer til Benyttelse ved Indsendelse af Prøver leveres Foreningerne gratis og portofrit ved Henvendelse til Danmarks geologiske Undersøgelse. Før Benyttelsen forsynes de i Hjørnet foroven til venstre med Foreningens eller Konsulentens Stempel eller Underskrift, for at man tydeligt kan se, hvortil Regning kan sendes. Prøver, der maatte indkomme uden Skemaer, tages ikke i Arbejde, før de tilsvarende Skemaer er indgaaede.

Nummerede Blikdaaser, egnede til Prøvernes Forsendelse, leveres paa samme Maade gratis og portofrit fra Danmarks geologiske Undersøgelse, men dog saaledes, at hver Sending Daaser debiteres Foreningen med 5 Øre pr. Daase, og at de Daaser, som indkommer med Prøver, atter godskrives Foreningen med samme Beløb.

Prøverne udtages efter den paa Bagsiden af Skemaerne anførte Vejledning. For hver Prøve udfyldes et Skema saa fuldstændigt som muligt.

Prøverne indsendes til Danmarks geologiske Undersøgelse, Gammelmønt 14, København K., enten af den stedlige Landbo- eller Husmandsforening (Konsulenten) eller af den enkelte Landmand. I det sidste Tilfælde maa det tydeligt fremgaa af Skemaet, til hvem Resultater og Regning kan sendes.

Undersøgelsens Resultater, der som Regel ikke kan ventes før ca. 14 Dage efter Prøvernes Modtagelse, sendes til Konsu- 
lenten eller en anden Mand, udpeget af den Forening, der har stemplet og udleveret Skemaet. Han maa sende Meddelelsen videre til Jordbrugeren samt give den fornødne Vejledning med Hensyn til Forstaaelsen og Udnyttelsen af Resultaterne.

Betalingen for Undersøgelsen er indtil videre fastsat til 50 Øre pr. Prøve. Jordprøver, udtagne i Forbindelse med lokale Markforsøg, undersøges dog gratis, naar der ved Indsendelsen benyttes et særligt Skema i Stedet for det almindelige. Beløbene føres Foreningen i Regning, og Opgørelse finder som Regel Sted kvartalsvis. Opgørelsen stiles til Foreningen og sendes til den, der har modtaget Resultaterne af Undersøgelsen.

De indsendte Skemaer skal bero hos Danmarks geologiske Undersøgelse, der ligesom de Landbrugsorganisationer, som har indsendt Jordprøverne, har Ret til eventuelt at benytte Resultaterne af Undersøgelserne til Offentliggørelse. 


\section{Vejledning}

ved Vurdering af Resultaterne af Undersogelserne over Jordens Kalktrang.

De indsendte Jordprøver undersøges som Regel paa 3 forskellige Maader, nemlig for: 1) Brusning med Syre, 2) Reaktion og 3) Forhold overfor Azotobacter. I enkelte specielle Tilfælde udføres yderligere: 4) Bestemmelse af klorammoniumopløselig Kalk.

Til Vurdering af de ved Undersøgelsen fremkomne Resultater anføres følgende:

\section{1) Syreprøven.}

Stærk Brusning viser, at Jorden er særdeles kalkrig og ikke i den nærmeste Fremtid kan ventes at blive kalktrængende.

Ingen Brusning bør ikke tydes som Tegn paa Kalktrang, men viser kun, at Jorden ikke, eller kun i ringe Mængde, indeholder Kalk i Form af kulsur Kalk. I saadanne Tilfælde, der er de hyppigst forekommende, maa man søge Vejledning i Resultaterne af de andre Undersøgelser.

2) Reaktionsbestemmelsen.

Bestemmelsen af Jordens Reaktion er navnlig oplysende for de tydeligt sure og de udpræget alkaliske Jorders Vedkommende.

Sur eller svagt sur Reaktion viser, at Jorden er stærkt kalktrængende.

Alkalisk eller stærkt alkalisk Reaktion viser, at Jorden ikke er kalktrængende.

Svagt alkalisk Reaktion vil i de fleste Tilfælde betyde, at Jorden ikke for Tiden er kalktrængende. Nærmere Vejledning maa dog her søges i Udfaldet af Azotobacterprøven.

Neutral eller tilnærmelsesvis neutral (neutral - svagt alkalisk og neutral - svagt sur) Reaktion oplyser intet om Jordens Kalktrang, idet Jorder med saadan Reaktion omtrent lige 
hyppigt er kalktrængende og ikke kalktrængende. Azotobacterprøven faar da her særlig Betydning.

3) Azotobacterprøven.

Kraftig Azotobactervegetation er et Tegn paa, at Jorden for Tiden ikke trænger til Kalk.

Svag Azotobactervegetation tyder paa, at Jorden staar paa Overgangen til at blive kalktrængende.

Ingen Azotobactervegetation er et Tegn paa, at Jorden enten er kalktrængende eller snart vil blive det.

De under 2 og 3 anførte Bemærkninger gælder kun for almindelige Agerjorder. Under enkelte særlige Forhold bør Resultaterne opfattes paa en noget anden Maade:

Ved vandsyge Jorder er sur Reaktion eller manglende Azotobactervegetation ikke noget sikkert Tegn paa, at Kalktilførsel vil være lønnende, idet en god og varig Virkning af Kalken ofte vil være betinget af, at Fugtighedsforholdene er i Orden.

Ved Humusjorder (Dyndjorder, tørveagtige Jorder, Mosejorder) behøver sur Reaktion eller manglende Azotobactervegetation ikke at være ensbetydende med Kalktrang, men kan lige saa godt være en Følge af mangelfuld Kultur (specielt daarlig Vandafledning). De nævnte Jordarter (og særlig Lavmosetørv) kan være meget rige paa Kalk, selv om de viser sur Reaktion, og Afvanding og Kultivering vil her ofte overflødiggøre Kalktilførsel. I saadanne Tilfælde kan en Bestemmelse af klorammoniumopløselig Kalk være af Betydning, idet et stort Kalkindhold (f. Eks. over $1 / 2 \%$ ) tyder paa, at "Surheden " vil kunne hæves ved, at Fugtighedsforholdene bringes i Orden.

For de meget svære (stive) Lerjorders Vedkommende maa den Mulighed siges at være til Stede, at Kalktilførsel kan være lønnende, selv om Jorden viser alkalisk Reaktion eller har foranlediget en kraftig Azotobactervegetation, idet Hensynet til Jordens Skørning kan være afgørende for Tilraadeligheden af Kalktilførsel.

Hvor det drejer sig om Bekæmpelse af visse ondartede Plantesygdomme - særlig Kaalbrok - vil Kalktilførsel godt kunne være virksom, selv om Jorden efter Reaktionen og navnlig efter Azotobactervegetationen at dømme ikke er kalktrængende.

Sikre Oplysninger om Nytten af Kalktilførsel i Tilfælde som de fire her omtalte vil kun kunne fremskaffes ved Forsøg eller Iagttagelse paa Stedet. 
Foreningens eller Konsulentens

Stempel eller Underskrift.

\section{Skema}

til Udfyldning ved Udtagning og Indsendelse af Jordprover til Bestemmelse af Jordens Kalktrang.

Jordprøve Nr. udtagen af (Stilling, Navn og Adresse)

den / 191, hos (Stilling, Navn, By-

navn, Postadr.)

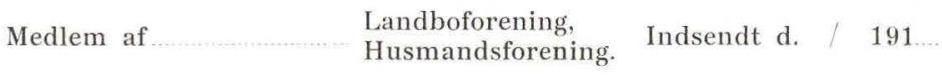

\begin{tabular}{c||c}
\hline Spørgsmaal: & Svar: \\
\hline
\end{tabular}

1. Jordens Art og Beskaffenhed:

a) Overgrund (herunder Oplysning om Muldholdighed og Mulddybde)?

b) Undergrund?

c) Gødningskraft ?

2. Jordens Fugtighedsforhold:

a) Er Jorden drænet, og da naar?

b) Trænger Jorden for Tiden til Afvanding?

c) Maa Jorden rettest betegnes: "sund ", vandsyg " (vaad og kold) eller ligefrem "sur"?

3. Jordens Forsyning med Mergel eller Kalk:

a) Har Jorden faaet Mergel eller Kalk, og da naar, hvormeget og med hvilken Virkning?

b) Den anvendte Mergels eller Kalks Kvalitet (særlig dens Indhold af kulsur Kalk)?

4. De forskellige Afgrøders Udvikling:

Hvorledes trives:

a) Rødkløver, Sneglebælg, o. a. Bælgplanter?

b) Runkelroer, Sukkerroer og Byg? 


\begin{tabular}{l||l}
\hline Spørgsmaal: & Svar: \\
\hline 5. Ukrudtsbestanden: \\
a) Optræder de saakaldte \\
kalksky Ukrudtsplan- \\
ter: Rødknæ,Vild Sper- \\
gel, Knavel, Blaa Sted- \\
moder, Gul Okseøje og \\
Kiddike 1) domineren- \\
de, 2) talrigt, 3) i ringe \\
Mængde, 4) kun enkelt- \\
vis, 5) slet ikke? \\
b) Hvilket andet Ukrudt \\
forekommer i større \\
Mængde? \\
\hline Sygdomsangreb: \\
Har Afgrøderne i den paa- \\
gældende Mark været an- \\
grebne af Sygdomme, sær- \\
lig Rodbrand, lys Pletsyge \\
og Kaalbroksvamp? \\
7. Andre Oplysninger af In- \\
teresse:
\end{tabular}

\section{Vejledning ved Prøveudtagningen.}

Inden for et Omraade af $1 / 100 \mathrm{Td}$. Land (ca. $150 \mathrm{Kv}$-Al.) graves paa 2-3 Steder Huller af Spadens Bredde og i en Dybde af 12 ". I to af Hullets modstaaende Sider afskæres ved et lodret Stik med Spaden eller ved Hjælp af en Planteske en Jordsøjle af samme Bredde for oven og for neden; den opsamles paa et Skovlblad, som holdes fast ind mod den paagreldende Side af Hullet, Jorden fra de enkelte Hulier blandes omhyggeligt paa et rent Underlag (et Stykke stift Papir, en ren Sæk el. lign.), og der udtages heraf en Gennemsnitsprøve paa ${ }^{1} / 2-1$ Pd., som fyldes i en Blikdaase (Cigarkasse eller Eske) og indsendes til Danmarks geologiske Undersøgelse, Gammelmønt 14, Kjøbenhavn $\mathrm{K}$.

Det paases, at saavel Daaser som Redskaber er rene, og at Laaget paa Daaserne lukkes omhyggeligt, hvilket bedst sker ved, at der lægges et Stykke Avispapir mellem Daasen og Laaget. Inden i Daasen (eller Esken) lægges, indsvøbt i Papir, en Følgeseddel, hvorpaa angives Afsenderens Navn og Adresse samt Prøvens Nummer.

For hver Prøve udfyldes et Eksemplar af omstaaende Skema, der mærkes med Prøvens Nummer og indsendes samtidig med Prøven. Forsendelsen sker bedst som Postpakke. 
Foreningens eller Konsulentens Stempel eller Underskrift.

\section{Skema}

vedrørende lokale Markforsøg til Udfyldning ved Udtagning og Indsendelse af Jordprover til Bestemmelse af Jordens Kalktrang.

Jordprove Nr. udtagen af (Stilling, Navn og Adresse) den / $191 \ldots$, hos (Stilling, Navn, By-

navn, Postadr.)

Medlem af $\quad \begin{aligned} & \text { Landboforening: } \\ & \text { Husmandsforening. Indsendt d. / } \quad 191 \ldots\end{aligned}$

\begin{tabular}{c|c}
\hline Spørgsmaal: & Svar: \\
\hline
\end{tabular}

1. Forsøget:

a) Forsøgets Art og Plan?

(De enkelte Spørgsmaal i

Forsøget anføres, og der tegnes et Rids af Forsøgsplanen med Afkrydsning af de Parceller, fra hvilke Prøven stammer.)

b) Hvornaar er Forsøget anlagt? (Dato og Aar.)

c) Hvornaar tænkes Forsøget afsluttet?

d) Foreligger der Høstresultater eller sikre Iagttagelser fra tidligere Aar. og hvorledes har disse da været? (Her kan henvises til trykte Beretninger.)

\section{Driftsforhold:}

a) Sædskiftet paa Forsøgsstykket? (for Gødningsforsøgenes Vedkommende helst med Angivelse af de Gødningsmængder (Staldgødning, Ajle el. kunstige Gødninger), der anvendes til de enkelte Afgrøder).

b) Afgrødens Art de enkelte Forsøgsaar?

c) Andre Oplysninger vedrørende Driften?

3. Jordens Art og Beskaffenhed:

a) Overgrund (herunder Oplysning om Muldholdighed og Mulddybde)?

b) Undergrund ?

c) Gødningskraft ? 


\begin{tabular}{l|l}
\hline Spørgsmaal: & Svar: \\
\hline
\end{tabular}

4. Jordens Fugtighedsforhold:

a) Er Jorden drænet, og da hvornaar?

b) Trænger Jorden for Tiden til Afvanding?

c) Maa Jorden rettest betegnes: "sund ", "vandsyg " (vaad og kold) eller ligefrem »sur«?

5. Jordens Forsyning med Mergel eller Kalk:

a) Har Jorden faaet Mergel eller Kalk, og da naar, hvormeget og med hvilken Virkning?

b) Den anvendte Mergels eller Kalks Kvalitet (sæerlig dens Indhold af kulsur Kalk)?

6. De forsk. Afgrøders Udvikling: Hvorledes trives:

a) Rødkløver, Sneglebælg, Lucerne o. a, Bælgplanter?

b) Runkelroer, Sukkerroer og Byg?

\section{Ukrudtsbestanden :}

a) Optræder de saakaldte kalksky Ukrudtsplanter: Rødknæ, Vild Spergel, Knavel, Blaa Stedmoder, Gul Okseøje og Kiddike 1) dominerende, 2) talrigt, 3) i ringe Mængde, 4) kun enkeltvis, 5) slet ikke?

b) Hvilket andet Ukrudt forekommer i større Mængde?

8. Sygdomsangreb:

Har Afgrøderne i den paagældende Mark været angrebne af Sygdomme, særl. Rodbrand, lys Pletsyge og Kaalbroksvamn?

\section{Andre Oplysninger af Inter-} esse:

Vejledning ved Prøveudtagningen.

Paa 5 a 6 Steder indenfor Forsøgsstykket, og ved allerede anlagte Gødningsforsøg altid $i$ de uggdede Parceller, graves der Huller af Spadens Bredde og $\mathrm{i}$ en Dybde af 12 Tommer. I to af Hullets modstaaende Sider afskares ved et lodret Stik med Spaden eller ved Hjælp af en Planteske en Jordsøjle af samme Bredde foroven og forneden; den opsamles paa et
Skovlblad, som holdes fast ind mod den paagreldende Side af Hullet. Jorden fra de enkelte Huller blandes omhygoligt pas et rent Underlas et Styke stift Papir, en ren Srk el. lion. og der udtages heraf en Gennemsnitsprove, som fyldes i en Blikdaase (Cigarkasse el. Eske) og indsendes til Danmarks geologiske Undersogels?, Gammelmont 14, Kjobenhavn K.

Hvor det af Hensyn til forsøgets gode Gennemforelse ikke godt lader sig gøre at grave Hullet inden for Forsøgsstykket, kan Prøven tages uden for dette. I saa Tilfielde graves der et Hul midt ud for hver af Forsogstykkets 4 Sider og i en Afstand af ca. 5 Alen fra disse. Prøverne fra de 4 Huller sammenblandes paa den ovenfor angivne Maade til en Fællesprøve. - Det paases, at saavel Daasen som Redskaberne er rene, og at Laaget paa Daasen lukkes omhyggeligt, hvilket bedst sker ved, at der lagges et Stykke Avispapir mellem Daasen og Laaget. Inden i Daasen (el. Fssken) lægges, indsvøbt i Papir, en Følgeseddel, hvorpaa angives Afsenderens Navn og Adresse samt Prøvens Nummer. - For hver Prøve udsamtidig med Prøven. Forsendelsen sker bedst som Postpakke. 
Nr. 5. K. Røвdaм. Beretning om en geologisk Undersøgelse paa Frænnemark ved Svaneke paa Bornholm. $1895 \ldots \ldots$. Pris $0,75 \mathrm{Kr}$.

- 6. K. Rørda.. Kridtformationen i Sjælland i Terræenet mellem København og Køge, og paa Saltholm. $1897 \ldots \ldots \ldots \ldots$.

- 7. K. Rørdam og C. Bartholin. Om Forekomsten af Juraforsteninger i løse Blokke i Moræeneler ved København. 1897 ....

- 8. Ethel G. Skeat and Victor Madsen. On Jurassic, Neocomian and Gault boulders found in Denmark. 1898 ..... .

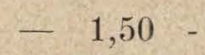

9. N. Hartz og E. Østrup. Danske Dialoméjord-Aflejringer og deres Diatoméer. $1899 \ldots \ldots \ldots \ldots \ldots \ldots \ldots \ldots$. . . . . . . . . . . . . .

- 10. Bidrag til Bornholms Geologi I. - K. A. GRönwall: Bemærkninger om Bornholms sedimentære Dannelser og deres tektoniske Forhold. J. P. J. Ravn: Trilobitfaunaen i den bornholmske Trinucleusskifer. A. Hловтн: Om Vellengsbyleret og dets Flora. N. V. Ussing: Sandstengange i Granit paa Bornholm. $1899 \ldots \ldots \ldots \ldots \ldots \ldots \ldots$. . . . . . . .

11. N. Hartz. Bidrag til Danmarks senglaciale Flora og Fauna. 1902...........

- 12. N. V. Ussing. Mineralproduktionen i Danmark ved Aaret 1900. 1902........

- 13. Karl A. Grönwall. Bornholms Paradoxideslag og deres Fauna. $1902 \ldots \ldots$.

- 14. Victor Madsen. Om den glaciale, isdæmmede Sø ved Stenstrup paa Fyn samt om Dannelsen af Teglværksleret i Stenstrup-Egnen. 1903 ..............

$1,75-$
$-\quad 2,00-$
$-\quad 2,00-$
$-\quad 6,00-$
$-\quad 2,00-$

- 15. Karl A. Grönwall. Forsteningsførende Blokke fra Langeland, Sydfyn og Arø, samt Bemærkninger om de ældre Tertiærdannelser i det baltiske Omraade.

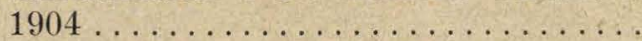

- 16. N. Steenberg og Poul Harder. Undersøgelser over nogle danske Sandsorters tekniske Anvendelighed. 1905 .......

- 17. Victor Madsen, V. Nordmann og N. Hartz. Eem-Zonerne. Studier over Cyprinaleret og andre Eem-Aflejringer i Danmark, Nord-Tyskland og Holland. $1908 \ldots$ - . 6,00 - 
Nr.18. Karl A. Grönwall og Poul Harder. Paleocæn ved Rugaard i Jydland og dets Fauna. $1907 \ldots \ldots \ldots \ldots \ldots$ Pris $2,50 \mathrm{Kr}$.

- 19. Poul Harder. En østjydsk Israndslinje og dens Indflydelse paa Vandløbene. $1908 \ldots \ldots \ldots \ldots \ldots \ldots \ldots \ldots \ldots$. . . . . . . . . . .

- 20. N. Hartz. Bidrag til Danmarks tertiære og diluviale Flora. $1909 \ldots \ldots \ldots \ldots$.

- 23. V. Milthers. Scandinavian Indicator-Boulders in the Quaternary Deposits. 1909

$6,00=$
$-6,00=$
$-\quad 3,00=$
$-\quad 1,25=$

III. Række.

\section{Populære Fremstillinger.}

Nr. 1. Oversigt over de af Danmarks geologiske Undersøgelse indtil Forataret 1895 udførte Arbejder.............. Pris $1,00 \mathrm{Kr}$.

- 2. N. V. Ussing. Danmarks Geologi i almenfatteligt Omrids. Første Udgave 1899. Anden Udgave 1904..............

- 3. V. Milthers. Foreløbig Beretning om en geologisk Rejse i det nordøstlige Tyskland og russisk Polen, foretaget i Forsommeren 1901. 1902 ............

- 4. V. Milthers. Grundrand og vandførende Lag i Danmark, særlig med Henblik paa Forsyningen af Brønde. $1903 \ldots$

- 5. V. Nordmann. Danmarks Pattedyr i Fortiden. $1905 \ldots \ldots \ldots \ldots \ldots \ldots \ldots$

- 6. Oversigt over de af Danmarks geologiske Undersøgelse i Aarene 1895-1904 udførte Arbejder, udgivet af Kommissionen for Danmarks geologiske Undersøgelse paa Grundlag af Indberetninger fra Geologerne. $1905 . \ldots \ldots \ldots \ldots \ldots$. 